\title{
Genetic Predisposition to Cutaneous Squamous Cell Carcinoma
}

\author{
Yi-Zhen Ng1,2, Jasbani H.S Dayal ${ }^{1}$ and Andrew P. South ${ }^{1}$ \\ ${ }^{1}$ Division of Cancer Research, Medical Research Institute, \\ Level 7 Clinical Research Centre, Ninewells Hospital and Medical School, \\ University of Dundee, Dundee, \\ ${ }^{2}$ Epithelial Biology Group, A*STAR Institute of Medical Biology, \\ ${ }^{1}$ UK \\ 2Singapore
}

\section{Introduction}

Ultraviolet (UV) radiation is the most ubiquitous mutagen known and as a direct result the skin is by far the most common site for cancer in Caucasian populations. In United Kingdom, non-melanoma skin cancer (NMSC) is the most frequent occurring cancer registration with over 98,854 cases in 2008, although estimates place it higher due to underreporting (CRUK, 2011a). Approximately three-quarters of NMSC are benign basal cell carcinomas (BCCs), while the remaining quarter consists predominantly of cutaneous squamous cell carcinomas (cSCC). NMSC accounts for 1 in 4 skin cancer deaths, the majority of which is attributed to the more malignant CSCC (Office for National Statistics). The overall prognosis is generally excellent for NMSC with only 491 deaths reported in UK in 2008 (mortality rate of 0.5 per 100,000 population) (CRUK, 2011b). However, those patients presenting with regional metastasis have poor outcome; 5-year survival in this group is 2550\% (Epstein, 1984; Veness et al., 2007).

A number of high-risk groups exist such as organ transplant recipients (OTR), patients with recessive dystrophic epidermolysis bullosa (RDEB) and xeroderma pigmentosum (XP), where individuals are predisposed to developing CSCC with considerable morbidity and mortality (Kraemer et al., 1994; Euvrard et al., 2003; Fine et al., 2009). The incidence of cSCC can be up to 250 times higher in OTRs compared to the general population (Hartevelt et al., 1990). Up to $70 \%$ of XP patients can develop malignant skin neoplasms (Kraemer et al., 1994). OTRs with metastatic skin cancer (mostly cSCC in regional lymph node basins) have a poor prognosis with 3-year disease specific survival of 56\% (Martinez et al., 2003). Comparatively, RDEB patients have a worse prognosis with more than $80 \%$ deaths from metastatic disease within 5 years of diagnosis of their first cSCC (Fine et al., 2009).

While great strides have been made in understanding the molecular pathogenesis of BCC, where mutations in PTCH1 or SMO result in aberrant patched/hedgehog intracellular signaling (Johnson et al., 1996; Xie et al., 1998; Epstein, 2008), the mechanisms and pathways implicated in CSCC are yet to be fully elucidated. This chapter will discuss what can be learnt from studying inherited diseases that predispose patients to developing cSCC. 


\subsection{Known molecular mechanisms in CSCC tumourigenesis}

Cancer is a genetic disease that arises as a result of an accumulation of structural and/or functional defects in the DNA double helix. The current paradigm for understanding tumourigenesis is crystallized by Hanahan and Weinberg in their 2000 and 2011 reviews where fundamental events termed "hallmarks of cancer" are required in the multi-step development of human tumours (Hanahan and Weinberg, 2000, 2011). Originally, six hallmarks of cancer were postulated: (i) sustaining proliferative signaling, (ii) evading growth suppressors, (iii) activating invasion and metastasis, (iv) enabling replicative immortality, (v) inducing angiogenesis and (vi) resisting cell death (Hanahan and Weinberg, 2000). A further two "emerging hallmarks" were later added: deregulation of cellular energetics and evasion of immune destruction. At the same time, two "enabling characteristics" which enable the acquisition of the hallmarks of cancer were also described. These are genomic instability and tumour-promoting immune response (Hanahan and Weinberg, 2011). In particular, genomic instability is "enabling" in the sense that it can lead to aberrant expression of key genes that can have an effect on important cellular mechanisms such as apoptosis, DNA repair, and proliferation.

Exposure to UV, particularly UV-B, can result in genetic abnormalities, notably mutations in the tumour suppressor TP53 gene, "the guardian of the genome" (Brash et al., 1991; Lane, 1992). Aberrant mutations in this gene have also been observed early on in solar keratoses (Taguchi et al., 1994), Bowen's disease (Campbell et al., 1993) and in $~ 58 \%$ of invasive cSCC (Brash et al., 1991). TP53 mutations are a widespread phenomenon in human tumours and have a unique UV signature $(\mathrm{C} \rightarrow \mathrm{T}$ dipyrimidine substitution) in skin tumours (Brash et al., 1991). In line with this, germline TP53 mutations in Li-Fraumeni patients can result in an early onset of cancer which includes, but is not limited to, cSCC. Li-Fraumeni, as a cSCC predisposing syndrome will be discussed later in greater detail in this review.

Another gene that has been associated with cSCC is the RAS oncogene. RAS was first implicated in the initiation of cSCC when $\mathrm{H}$-ras mutations were found in the benign papillomas of mice treated with the 7,12-dimethylbenz[a]anthracene (Balmain et al., 1984). In laboratories, expression of oncogenic RAS in human keratinocytes was able to recapitulate tumours in mice (Boukamp et al., 1990; Dajee et al., 2003). However the data based on RAS mutations in human CSCC is ambiguous. Various independent studies conducted thus far have revealed heterogeneity in their expression and correlation to cSCC development. In North African XP patients, RAS genes were found to be at least twice as mutated (50\%) compared to control tumours (22\%) (Daya-Grosjean et al., 1993). In contrast, a separate study found only 1 mutation in 26 cSCCs from XP patients (Sato et al., 1994). Our lab have demonstrated lack of RAS mutations in 10 cSCCs (Pourreyron et al., 2007) while whole exome sequencing have recently identified activating HRAS mutation in only one from 8 cSCC (Durinck et al., 2011). This whole exome sequencing study also identified a high proportion of truncating mutations in NOTCH1 and NOTCH2 genes, an observation also reported in head and neck SCC (Agrawal et al., 2011; Stransky et al., 2011), suggesting that NOTCH may act as a tumour suppressor in a high proportion of SCC. The identification of an increased risk of developing well differentiated cSCC in patients receiving kinase inhibitors, particularly melanoma patients receiving B-RAF inhibitors (Arnault et al., 2009; Flaherty et al., 2009), has rekindled interest in this area, especially since the identification that inhibition of RAF, which is downstream of RAS, can lead to RAS hyperactivation (Heidorn et al., 2010; Poulikakos et al., 2010). Whether 
there is a difference between inhibitor (chemically) induced CSCC, and UV induced cSCC remains to be investigated.

Further genes such as cell cycle inhibitor CDKN2A (Brown et al., 2004), MYC (Pelisson et al., 1996) and PIK3CA (Waterman et al., 2007) have also been implicated in cSCC development (Green and Khavari, 2004). Although these correlations provide clues to the pathways involved in CSCC pathogenesis, definitive causal relationships remain elusive.

Here we focus on CSCC and review the genetic and molecular basis behind inherited disorders which are associated with a predisposition to CSCC. In particular, we will examine what is currently known about the pathogenesis in the patient group where CSCC has the biggest impact on mortality - RDEB.

\section{Cancer predisposition}

Abnormalities in tumour suppressor genes (TSG) and/or oncogenes (OG) that control important cellular mechanisms which are crucial for normal cell functioning can either be acquired during an individual's lifetime or inherited and predispose individuals to cancer. Clinically, an individual is suspected of an inherited predisposition to cancer if (i) other family members have been diagnosed with cancer, (ii) cancer is detected at a young age, (iii) multifocal or bilateral primary tumours are formed or (iv) two or more primary tumours are detected. This inherited predisposition to cancer or familial cancer syndrome (FCS) accounts for $5-10 \%$ of all reported cancers and is characterised by mutations, deletions and amplifications of specific TSG's and/or OG's within affected families.

Linkage analysis and positional cloning has enabled the identification of key high penetrance genes responsible for cancer predisposition such as the BRCA1 (Hall et al., 1990; Narod et al., 1991; Miki et al., 1994) and BRCA2 (Wooster et al., 1995) genes in breast cancer and CDKN2A in melanoma (Goldstein et al., 2001). However, a mutation in such high penetrance genes is only detected in $\sim 25 \%$ of familial cancers, thereby suggesting the prevalence of more complex and diverse molecular and genetic interactions in cancer predisposition. Genome wide association studies (GWAS) of affected families have also allowed the identification of other low penetrance genes, suggesting the involvement of multiple gene clusters in cancer susceptibility. This may also enable a better understanding of the genetic mechanisms underlying sporadic cancers (Hemel and Domchek, 2010).

\subsection{Familial cancer syndromes and cSCC predisposition}

A number of FCS are associated with an increased risk of developing cSCC: Blooms syndrome, Cowden syndrome, Fanconi anemia, Li-Fraumeni syndrome (LFS), RothmundThomson syndrome (RTS), Werner's syndrome and xeroderma pigmentosum. A significant number of individuals within affected families have been shown to carry mutations in specific DNA repair genes that subsequently increase the risk of developing skin cancer, such as BLM (Blooms syndrome), PTEN (Cowden syndrome), FANCA-N (Fanconi's Anemia), TP53 (LFS), RECQL4 (RTS), WRN (Werner's syndrome), and XPA-G (XP).

\section{Blooms syndrome}

Blooms syndrome is a rare autosomal recessive disorder characterised by genomic instability. The BLM gene that resides on chromosome $15 q 26.1$ is a member of the DNA helicase family and is commonly mutated in individuals diagnosed with Blooms syndrome. A loss of function of this gene results in error prone DNA repair and replication (Ellis et al., 
1995; German et al., 2007). Due to increased chromatin exchange and extensive chromosomal instability observed in these individuals, this disease is also referred to as the chromosome breakage syndrome.

The phenotypic characteristics of individuals with Blooms syndrome include severe growth retardation, small stature, infertility, diabetes and chronic pulmonary disease. Skin specific abnormalities appear after first exposure to sunlight and manifest as an erythematous telangiectatic rash. Due to photosensitivity, skin cancer, in particular, cSCC develops in $\sim 14 \%$ of individuals and is diagnosed at a mean age of 31.8 years (German, 1997). However, the most common cause of death in Blooms syndrome patients is due to other malignancies such as leukemia and lymphoma.

\section{Cowden syndrome}

Cowden syndrome is inherited in an autosomal dominant pattern and is characterised by the development of multiple hamartomas. This disease involves the loss of function of the phosphatase and tensin homolog (PTEN) in about $80-85 \%$ of affected individuals (Li et al., 1997; Liaw et al., 1997; Nelen et al., 1996). PTEN is a tumour suppressor gene that negatively regulates the protein kinase $B$ (AKT) signaling pathway, which in turn inhibits the phosphorylation and regulation of key genes known to assist carcinogenesis by increasing cell proliferation and anti-apoptotic activity (Segrelles et al., 2002).

Reduced PTEN levels in mice have been previously shown to aid malignant transformation of skin lesions in cSCC (Ming and He, 2009; Suzuki et al., 1998). PTEN null mice with mutations specifically induced in keratinocytes exhibit hyperkeratosis and epidermal hyperplasia along with the development of cSCC and papillomas. Additionally, these mutant mice have ruffled and shaggy hair with cuticles separated from their hair shafts (Suzuki et al., 2003). A more recent study has also suggested a role of UV-B radiation in the suppression of PTEN via the ERK/AKT signaling pathway in mouse skin (Ming et al., 2009). The estimated risk of developing Cowden syndrome is 1 in 200,000 with the majority of cases presenting thyroid, breast and endometrium tumours (Starink et al., 1986). Although $>90 \%$ of affected individuals present abnormalities of the skin including, acral keratoses and trichilemmomas, most of these lesions are not neoplastic and do not contribute towards skin cancer related deaths (Blumenthal and Dennis, 2008).

\section{Fanconi anemia}

Fanconi anemia is a rare genetic disease that can either be inherited in an autosomal recessive or X-linked recessive manner. Thirteen genes involved in the inheritance of this disease have so far been identified but the mechanism underlying their interaction is not fully understood (Bagby, 2003; Bagby and Alter, 2006). Some of these genes are associated with breast cancer susceptibility such as the FANCD1, which was identified as the BRCA2 gene (Howlett et al., 2002) and FANCJ, also known as BRIP1 (Seal et al., 2006).

This disease is characterised by an increase in the number of chromosome breaks and bone marrow failure in affected individuals. A number of heterogeneous physical birth defects such as, short stature, dangling thumbs, microcephaly and dislocated hips are also observed. Clinically, this disease can be identified by the use of DNA cross-linkers such as mitomycin- $C$ that increase the rate of chromosome breaks in cultured Fanconi anemia primary cells (Poon et al., 1974).

The risk of developing cancer in individuals diagnosed with Fanconi anemia is estimated at $76 \%$ by 45 years of age (Alter, 2003). The majority of people diagnosed are predisposed to 
leukemia, in particular, acute myeloid leukemia ( 95\%), hepatocellular carcinoma and Wilm's tumours (Alter and Olson, 2009). Only a fraction of individuals are diagnosed with NMSC and no studies have reported any significant number of aggressive or metastatic cSCCs.

\section{Li-Fraumeni syndrome}

Families with Li-Fraumeni cancer syndrome are predisposed to NMSC that include cSCC (Benjamin and Ananthaswamy, 2007; Srivastava et al., 1992). Up to 60\% of LFS individuals have mutations in the TP53 tumour suppressor gene (Malkin, 1994). The TP53 gene is a transcription transactivator that resides on chromosome 17p13.1 and is reported to be mutated in $\sim 60 \%$ cSCC patients (Brash et al., 1991). This gene is activated in response to DNA damage that can result from exposure to UV radiations. In particular, TP53 has been shown to protect skin cells from damage caused by exposure to UV-B radiation (Smith and Fornace, 1997). Hence, cells with mutant TP53 gene are unable to maintain the integrity of their DNA, which can lead to the development of precancerous skin lesions known as actinic keratosis. Although a small number of individuals with LFS are predisposed to cSCC, there are no reports associating LFS with cSCC related mortality. LFS families instead have a higher susceptibility of developing life threatening brain tumours, soft tissue sarcoma and breast cancer (Olivier et al., 2003).

\section{Rothmund-Thomson syndrome}

Rothmund-Thomson syndrome is an inherited autosomal recessive disorder that is predominantly associated with poikiloderma of the face, neck and extremities. It has been previously reported that $5-10 \%$ of RTS individuals are predisposed to skin cancer, with cSCC being the most common type. Approximately, two thirds of RTS patients have mutations in the RECQL4 gene (Kitao et al., 1999), which is a member of the RecQ DNA helicase family and resides on chromosome 8q24.3. A normal function of this gene is required to suppress random DNA recombination and assist in DNA repair and proper chromosome segregation. A mutation in the RECQL4 gene is associated with abnormalities of chromosome 8 including both numerical (trisomy 8) and structural (duplication of part of chromosome $8 \mathrm{q}$ ) aberrations. Karyotypic analysis have confirmed a gain of chromosome $8 \mathrm{q}$ in a significant number of cSCC patients (Jin et al., 1999), thereby suggesting an underlying link between genes residing on chromosome 8 (RECQL4, cMYC) and CSCC predisposition in a subset of RTS patients. Although a significant number of RTS patients are associated with cSCC with multiple cSCCs diagnosed at an early age (Haneke and Gutschmidt, 1979; Borg et al., 1998), the exact underlying mechanism and the incidence of metastasis has not been extensively studied.

\section{Werner's syndrome}

Werner's syndrome or progeria adultorum (premature aging of adults) is mainly associated with thin, tight skin, short stature, bilateral cataracts, graying and thinning of hair and sclerodermatous skin changes. Like Blooms syndrome, Werner's syndrome is inherited in an autosomal recessive manner and is also associated with chromosomal instability and increased cancer susceptibility. More than $90 \%$ of Werner's syndrome patients carry a mutation in the WRN gene residing on chromosome 8p12, which is involved in important cellular mechanisms such as DNA repair, replication and recombination (Huang et al., 2006). The average life expectancy of individuals diagnosed with Werner's syndrome is $45-50$ years with an early onset of carcinogenesis in a significant number of patients (40\%) and a high 
incidence of thyroid and skin cancer (Yamamoto et al., 2003). Individuals diagnosed with this syndrome are 10 times more likely to develop epithelial cancers and sarcomas. The majority of skin cancers ( $20 \%$ ) diagnosed are acral lentiginous melanomas (up to $14 \%$ ) and relatively aggressive cSCC's (5\%) that metastasise to the lymph nodes and internal organs (Machino et al., 1984). It has been previously reported that malignant tumours occur at an average age of 41 years in the Japanese population diagnosed with Werner's syndrome. There is further evidence to suggest higher cancer related mortality $(6.1 \%)$ than the Japanese general population $(0.3 \%)$ as a result of metastasis (Yamamoto et al., 2003).

\title{
Xeroderma Pigmentosum
}

Xeroderma Pigmentosum is an inherited autosomal recessive neurocutaneous disorder that is caused as a result of mutations in genes involved in the nucleotide excision repair (NER) mechanism. XP patients have heterogeneous mutations in these genes and are grouped accordingly into seven groups (XP-A to XP-G) (Kraemer, 1993; Kraemer et al., 2007). This disease is phenotypically characterised by dry, pigmented skin with premature ageing and photosensitivity. In addition to skin abnormalities, neurological defects including microcephaly and spasticity are also observed. It has been previously reported that up to $70 \%$ of XP patients develop malignant skin neoplasms, in which $\sim 50 \%$ are NMSC (Kraemer et al., 1994). The incidence of metastasis in XP related CSCC is reported to be $4 \%$, which is comparable to the general population (2-4\%) (Kraemer et al., 1987). Other neoplasms associated with XP include brain and lung cancer but the relative incidence of developing these tumours is lower compared to skin cancer.

\subsection{Inherited skin disorders and CSCC predisposition}

Hereditary skin disorders that result in photosensitivity, ulceration or blistering of the skin can also be complicated by cSCC predisposition. These include, albinism, Bazex syndrome, Darier disease, epidermolysis bullosa (EB), epidermodysplasia verruciformis (EV), Ferguson-Smith diesease, Huriez syndrome, Keratitis-Ichthyosis-Deafness (KID) and XX sex reversal with palmar plantar keratoderma, and will be discussed below. Although all of the aforementioned skin disorders contribute to the development of $\mathrm{CSCC}$, the recessive dystrophic subtype of EB is associated with by far the highest CSCC related mortality and will be discussed in detail in section 3 (Reed et al., 1975; Fine et al., 2009).

\begin{abstract}
Albinism
Albinism is a heterogeneous group of disorders with an autosomal recessive inheritance pattern and is associated with aberrant melanin production. Albinism can be broadly grouped into (i) oculocutaneous albinism (OCA) and (ii) ocular albinism (OA). Individuals diagnosed with OCA have low levels of melanin in the skin, eyes and hair and are characterised by pale light skin that is photosensitive and prone to developing skin cancer (Perry and Silverberg, 2001). OA on the contrary is mainly associated with abnormal pigmentation of the optic system with no differences observed in the skin of the affected individuals

Three OCA subcategories exist as per the genetic classification of the disease, OCA1 (tyrosinase gene, 11q14-21), OCA2 (P protein gene, 15q11-13) and OCA3 (tyrosinase related gene, 9p23) (Summers, 2009). Mutations in the tyrosinase gene causes type 1 OCA. The enzyme tyrosinase is involved in the conversion of tyrosine into melanin (by converting dopaquinone to either eumelanin or pheomelanin) that protects skin cells against the
\end{abstract}


deleterious effects of UV radiations (Oetting and King, 1993). Type 2 OCA results from mutations in the gene encoding the $\mathrm{P}$ protein (pink-eyed dilution protein homolog or melanocyte-specific transporter protein) that is responsible for the transport of tyrosine prior to melanin production by melanocytes (Saitoh et al., 2000). The third type of OCA is caused due to the mutations in tyrosine related proteins 1 and 2 that are involved in the production of eumelanin. In a study involving 111 South African (black population) albinos, the incidence of NMSC was reported to be as high as $23 \%$. Additionally, BCC was found to be less common than cSCC in these individuals (Kromberg et al., 1987; Kromberg et al., 1989).

\section{Bazex syndrome}

Acrokeratosis paraneoplastica or Bazex syndrome is a rare inherited skin disorder (Bazex and Griffiths, 1980). This disease presents in the form of psoriasiform-erythematous plaques in the hands, feet, nose and earlobes. The most common feature of Bazex is the occurrence of an internal malignancy along with one of the cutaneous psoriasiform lesions (Pecora et al., 1983; Sharma et al., 2006). The most frequently occurring malignancy in Bazex syndrome is SCC of the aero-digestive tract. In some cases cervical lymph node metastasis is also reported where the primary tumours have not been identified (Viteri et al., 2005). Bazex syndrome is not primarily linked with CSCC and the number of cases reported in literature are low (Hara et al., 1995) with no indication of cSCC associated mortality and/or metastasis (Sarkar et al., 1998)

\section{Darier disease}

Darier-White disease or keratosis follicularis is an autosomal dominant inherited skin disorder characterized by the occurrence of wart-like, yellowish and mildly greasy blemishes that emit a strong odor. In some cases abnormalities of the nail and mucous membrane have been observed such as having an irregular nail texture and blemishes on gums, tongue and throat. Epilepsy and learning disabilities have also been reported in some affected individuals. The prevalence of Darier disease is estimated at 1 in 30,000 in Scotland alone. Lower number of cases are reported from other countries such as Denmark ( 1 in $100,000)$ and Wales $(1$ in 36,000) but the worldwide prevalence of this disease is unknown (Sehgal and Srivastava, 2005).

Mutation in the ATP2A2 gene located on chromosome 12q23-24.1 is responsible for this disease (Sakuntabhai et al., 1999a; Sakuntabhai et al., 1999b). However, the severity of the disease has been shown to vary between individuals carrying the same mutation due to environmental factors such as exposure to UV radiation and hot climatic conditions. A mutation in the ATP2A2 gene reduces the level of its' protein product the SERCA2 enzyme (an intracellular $\mathrm{Ca}^{2+}$ pump), which in turn reduces calcium levels in the endoplasmic reticulum, rendering it dysfunctional (Byrne, 2006). The complete molecular mechanism underlying the ATP2A2 gene mutation causing blemishes solely localized to the skin is not fully understood. However, it has been postulated that skin cells are the only cell type without a backup system for calcium transport, therefore the disease manifests in the skin even if SERCA2 is expressed in other organs. Further preliminary studies have also shown that synthesis and trafficking of desmosomal proteins can be altered as a result of low calcium levels (Dhitavat et al., 2004). Moreover, abnormal expression levels of keratin 10 and 14 have also been associated with altered calcium regulation in Darier disease (Leinonen et al., 2009).

The most serious complication of Darier disease is the onset of bacterial and viral infections that can lead to fatal outcomes. Anecdotal case studies have reported cSCC in Darier disease 
(Orihuela et al., 1995; Downs et al., 1997; Vazquez et al., 2002) but none have reported metastasis related mortality and the life expectancy of these individuals is comparable to the normal population.

\section{Epidermolysis Bullosa}

Inherited EB is a group of rare skin fragility disorders characterized by chronic blistering of the skin and mucosae following minor mechanical trauma. Based on a large American study, EB incidence was reported to be 19.6 per million live births between 1986 and 1990 along with a prevalence of 8.22 per million within the population studied (Fine et al., 1999) In the revised 2008 classification, EB is divided into four main groups based on the ultrastructural level of blister formation in the basement membrane zone (BMZ) (Fine et al., 2008). The four groups are EB simplex (EBS), junctional EB (JEB), dystrophic EB (DEB) and Kindler syndrome (KS), and have either intraepidermal, intra-lamina lucida, sub-lamina densa or a mixed level of dermal-epidermal cleavage, respectively. Kindler syndrome (KS), RDEB and JEB are associated with a predisposition to developing CSCC (Fine et al., 2009; Yazdanfar and Hashemi, 2009; Yuen and Jonkman, 2011) of which JEB and KS will be discussed here and RDEB later in Section 3.

\section{Kindler syndrome}

Kindler syndrome (KS) is associated with photosensitivity, extensive skin blistering, and progressive poikiloderma. It is a rare autosomal recessive disorder caused as a result of mutation in the FERMT1 gene that resides on chromosome 20p12.3 (Siegel et al., 2003). This gene encodes a protein (kindlin-1) that is involved in linking the actin cytoskeleton with the extra cellular matrix (ECM) and regulating the secretion of various basement membrane factors by the basal keratinocytes. KS unlike other skin related disorders results from defects in the actin-ECM interaction instead of the keratin-ECM interaction (Ashton et al., 2004; Arita et al., 2007).

Up to $10 \%$ of individuals suffering from KS develop NMSC, mostly cSCC, with the youngest patient reported being a 16 year old boy (Arita et al., 2007; Lai-Cheong et al., 2009; Yazdanfar and Hashemi, 2009). Owing to a low incidence of KS (only about 100 cases reported worldwide) a detailed analysis of metastasis and cSCC related death has not been possible. However, anecdotal case studies have reported the prevalence of aggressive CSCC that metastasise to the axillary lymph nodes. These cSCC tumours have been shown to recur following radiation therapy, thereby necessitating amputation of the affected limbs (Emanuel et al., 2006).

\section{Junctional Epidermolysis Bullosa}

JEB is inherited in an autosomal recessive manner and is characterized by skin cleavage in the lamina lucida of the BMZ. JEB can be further classified into two main subtypes - the lethal JEB- Herlitz (JEB-H) and JEB-other. In JEB-H, there is a lack of laminin-332 expression (laminin-5) due to premature termination codon mutations in the gene of any of the three polypeptide components (LAMA3, LAMB3 and LAMC2) of laminin 332 (Christiano and Uitto, 1996; Kivirikko et al., 1996). Extensive blistering occurs soon after birth. Due to the severe blistering and fragile internal mucosae, most infants die early. JEB-other (includes localized and generalized non-Herlitz JEB and JEB with pyloric atresia), may involve type XVII collagen or $\alpha 6 \beta 4$ integrin gene in addition to laminin-332 (McGrath et al., 1995; Kivirikko et al., 1995; Vidal et al., 1995). Patients usually survive to adulthood in generalized non-Herlitz JEB as severity of the disease decrease with age. 
Although, an association between JEB and CSCC was not found in the large study conducted by Fine and colleagues (Fine et al., 2009), a recent retrospective study of 28 non-Herlitz JEB patients revealed an increased incidence of aggressive CSCC, albeit at a lower frequency than in sg-RDEB patients with a lifetime risk of 25\% (Yuen and Jonkman, 2011). The first cSCC occurred at an average age of 50. Multiple cSCCs were common and tended to be in the lower extremities (Yuen and Jonkman, 2011).

\section{Epidermodysplasia Verruciformis}

Human papillomavirus (HPV) infection has long been implicated in the development of cSCC in the rare genodermatosis epidermodysplasia verruciformis (EV) (Orth et al., 1978). Mutations in EVER1 and EVER2 genes result in susceptibility to beta- human papillomavirus ( $\beta$-HPV) infection and a high risk of skin cancer - about $50 \%$ of the patients eventually develop cSCC (Ramoz et al., 2002). Onset of lesions usually appears within the first decade, with CSCCs appearing at an average age of 20 at sun-exposed areas (de Oliveira et al., 2003; Gul et al., 2007). Although the tumours are generally localized, aggressive metastatic cSCCs resulting in mortality have been reported (Kaspar et al., 1991; de Oliveira et al., 2003; Gul et al., 2007).

Due to the high incidence of CSCC in transplant patients it has long been postulated that a viral etiology exists. However, a role of HPV has long been debated (Harwood and Proby, 2002) and the available data are not clear. Transgenic mice expressing the complete early regions of HPV8 develop skin papillomas and varying degrees of epidermal dysplasia, with $6 \%$ of the transgenic mice eventually developing malignant tumours (Marcuzzi et al., 2009). In humans although associations were found between HPVs and CSCC in the general population (Masini et al., 2003), the ubiquitous presence of the various HPV types in normal skin makes it difficult to draw any definitive conclusions (Astori et al., 1998). Recently, Arron and colleagues were able to show conclusively by harnessing transcriptome sequencing technology that $\beta$-HPV is not active in CSCC, thereby demonstrating no role for HPV in maintaining CSCC tumours (Arron et al., 2011). However this data does not exclude a role for HPV in tumour initiation.

\section{Ferguson-Smith disease}

Multiple self-healing squamous epithelioma or Ferguson-Smith disease is associated with the occurrence of multiple invasive skin tumours that spontaneously heal leaving pitted scars and is mainly reported in individuals originating from western Scotland (FergusonSmith et al., 1971). Recently, this autosomal dominant inherited skin disease was linked to mutations in the TGFBR1 gene on chromosome 9q22.33 (Goudie et al., 2011). This gene encodes a protein that aids in the transduction of TGF-beta signaling from the cell to the cytoplasm, thereby, assisting in the regulation of important cellular mechanisms including cell division, differentiation and adhesion. As the name suggests, this disorder involves the development of multiple self-healing cSCCs that emerge and regress with no cases of metastasis or mortality having been reported. Whether TGFBR1 mutations are common in the large proportion of benign and sometimes spontaneously regressing cSCC is unknown.

\section{Huriez syndrome}

Huriez syndrome is characterised by palmoplantar keratoderma, congenital scleroatrophy and hypoplasia of the nails. This syndrome is inherited in an autosomal dominant manner and linkage analysis has enabled the mapping of possible Huriez syndrome susceptibility genes on chromosome 4q23 (Lee et al., 2000). Huriez disease is often associated with 
aggressive and metastatic cSCC (Hamm et al., 1996). cSCC develops in $~ 15 \%$ of individuals diagnosed with this disease (Sekar SC, 2008), especially in the scleroatrophic areas in the affected individuals. The clinical manifestations of cSCC in Huriez syndrome are very similar to Marjolin's ulcer where malignant lesions appear in ulcers, scarred and/or burnt tissue. Further parallels exist between Marjolin's ulcer and RDEB, and will be discussed further in section 3 .

\section{Keratitis-Ichthyosis-deafness}

KID was first coined in 1981 (Skinner et al., 1981) owing to the three distinct phenotypic characteristics including vascularising keratitis, localized or generalised skin ichthyosis and severe hearing disability. Since its first description in 1915, approximately 100 cases have been reported so far in literature. KID is a rare genetic disorder that is inherited in an autosomal dominant pattern. Mutations in the GJB2 gene encoding the gap junction protein Connexin 26 are reported in affected individuals (Terrinoni et al., 2010). Gap junctions are membrane channels connecting adjacent cells, which are involved in the reciprocal transport of small molecules and ions including $\mathrm{Ca}^{2+}$ between neighboring cells. These junctions play an important role in cell proliferation, growth and differentiation.

A significant percentage of KID syndrome patients have been diagnosed with follicular tumours and cSCC (Madariaga et al., 1986; Conrado et al., 2007). The largest study ( $\mathrm{n}=14)$ to date has shown that about $29 \%$ of affected individuals develop CSCC and SCC of the oral mucosa at an early age with the mean age of 25 years (Mazereeuw-Hautier et al., 2007). Although, some studies have documented the occurrence of cSCC in KID syndrome, most of these are less aggressive forms with no reports of metastasis or cSCC related deaths.

\section{XX sex reversal and Palmar Plantar Keratoderma}

XX sex reversal and Palmar Plantar Keratoderma (PPK) reported in a Sicilian family also predisposes to cSCC (Micali et al., 2005). Since, none of the females in the affected family were diagnosed with PPK or sex reversal, the study spanning three generations has suggested that loss of function of a single gene is responsible for PPK, sex reversal and subsequent cSCC predisposition (Radi et al., 2005). Linkage analysis has led to the identification of a locus on chromosome 1q34-35 and further sequencing studies have enabled the isolation of a homozygous mutation in the RSPO1 gene (Parma et al., 2006), which is shown to enhance Wnt signaling. Although, the males carrying the 46XX genotype along with PPK are reported to develop cSCC that metastasizes to other internal organs, the cSCC related incidence has not been fully reported due to the low number of cases documented in literature.

\section{Recessive Dystrophic Epidermolysis Bullosa}

DEB is caused exclusively by mutations in the COL7A1 gene which encodes type VII collagen (Ryynänen et al., 1991; Hovnanian et al., 1992; Christiano et al., 1994). Type VII collagen is the main constituent of anchoring fibrils, which secure the basement membrane to its underlying dermis (Burgeson, 1993). Both keratinocytes and fibroblasts are able to synthesise type VII collagen (Marinkovich et al., 1993; Vindevoghel et al., 1997; Woodley et al., 2003). Ultra-structurally, DEB is characterized by skin cleavage at the sub-lamina densa with absent or reduced anchoring fibrils, leading to skin blistering (Tidman and Eady, 1985; McGrath et al., 1993; Uitto et al., 1994; Uitto et al., 1999). As the skin cleavage occurs below the basement membrane, blisters form in the dermis and tend to heal with scar formation 
(Bruckner-Tuderman, 2001). Other typical clinical manifestations of DEB are nail dystrophy and milia formation.

This genetic disorder can be inherited either as an autosomal dominant (DDEB) or recessive (RDEB) trait. Blistering severity in DEB patients varies considerably. In general, RDEB differs clinically from DDEB in that it is significantly more debilitating - mild friction is sufficient to induce blisters in RDEB, whereas considerable force like sharp knocks and glancing blows are required in DDEB (Eady et al., 2004). In addition, blistering can extend to the oral cavity, gastro-intestinal tract and eyes in RDEB patients, leading to soft tissue scarring, microstomia, ankyloglossia and dental caries (Fine et al., 2008; Fine and Mellerio, 2009). Importantly and unlike RDEB, no evidence for an increased incidence of CSCC was reported in a large study of 442 DDEB patients (Fine et al., 2009) although case reports do exist in the literature (Song and Dicksheet, 1985; McGrath et al., 1992b; Christiano et al., 1999).

RDEB is further sub-divided on the basis of clinical features into: RDEB severe generalized, RDEB generalized other and RDEB inversa (Fine, 1999; Fine et al., 2009). RDEB severe generalized (sg-RDEB, previously known as RDEB Hallopeau-Siemens) is, as the name suggests, the most severe mutilating subtype of RDEB. There is severe blistering and extensive atrophic scarring and the patients are usually anaemic. As a result, physical development is stunted, with delayed puberty and osteoporosis. RDEB generalized other (RDEB-O, previously known as mitis RDEB) is the second major form of RDEB. While it shares many cutaneous and extracutaneous similarities with sg-RDEB, RDEB-O generally has milder clinical manifestations, with blistering and scarring that is more comparable to that in DDEB. In the third classification - RDEB inversa (RDEB-I), blisters are present at birth but later become localized to acral areas as well as skin folds such as lateral neck, groin and axillary vaults.

The most severe form of RDEB, sg-RDEB is primarily associated with nonsense mutations, insertions, deletions or out-of-frame splicing mutations in both alleles of COL7A1, which produce frameshift and/or premature termination codons (PTC). PTC mutations lead to mRNA instability, resulting in dramatic reduction or a complete absence of anchoring fibrils in the skin, thereby causing a more severe disease phenotype (Christiano et al., 1997; Uitto and Richard, 2004; Varki et al., 2007). In RDEB-O, missense mutation or in-frame deletion in one or both COL7A1 alleles leads to the altered conformation of polypeptides. This altered conformation prevents the proper assembly of the polypeptides into anchoring fibrils. Therefore, only some anchoring fibrils are observed under electron microscope or detected using immunohistochemistry methods (Uitto and Richard, 2004; Varki et al., 2007). These mutant anchoring fibrils are not able to fulfill their role in dermal-epidermal adhesion, which is consistent with the phenotype of moderate blistering observed in this DEB subtype (Woodley et al., 2008).

\subsection{RDEB patients develop malignant cSCC}

Case reports of multiple, metastatic and life-threatening skin cancer in RDEB patients arising on damaged tissue date as far back as 1975 (Reed et al., 1975). A recent study examined the risk for skin cancer over a 20-year period in the 3280 EB patients in the US EB registry, the largest cohort to date, convincingly demonstrated that RDEB patients, comprising 421 individuals, are at high risk of developing aggressive and life-threatening CSCC (Fine et al., 2009). The cumulative risk of developing CSCC in patients with severe-generalized RDEB (sg-RDEB) stands at more than $90 \%$ by the age of 50 (Fine et al., 2009). While there have been a few cases of malignant melanoma in RDEB (Chorny et al., 1993; Fine et al., 2009) the overwhelming 
majority of the tumours that occur in RDEB patients are CSCC. A correlation exists between severity of blistering and development of cSCC. The cumulative risk of developing cSCC is highest in sg-RDEB (where skin blistering is most severe and extensive) followed by RDEB-O (which has milder clinical manifestations) and finally RDEB-I (where blistering becomes localized to acral areas and skin folds with age). This is further supported by the observation that the most common site for CSCCs in RDEB is persistent skin wounds followed by longterm cutaneous scars rather than sun-exposed areas. However, no detailed analysis has been carried out to examine the COL7A1 mutation spectrum in a large cohort of RDEB patients who eventually develop cSCC. Such clinical, genetic and immunohistological data could shed further light on the relationships between the loss of type VII collagen, formation of anchoring fibrils, severity of blistering and the risk of developing CSCC.

Perplexingly, although most CSCCs in RDEB patients are histo-pathologically moderately differentiated (McGrath et al., 1992b), these cSCCs are biologically aggressive and have the propensity to recur or metastasize to distant sites, eventually causing the death of the patient. In fact, most RDEB patients will develop multiple cSCCs (median number per RDEB patient $=3-3.5$ ) and die from metastatic disease despite surgical excision (Fine et al., 2009). The cancer survival rates for RDEB patients are dismal: more than $80 \%$ die from metastatic CSCC in 5 years after initial tumour presentation. These statistics stand in stark contrast to those of the general US population where the lifetime risk of developing cSCC is only $7-11 \%$ and the overall mortality rate for NMSC considerably lower at 0.69 per 100,000 per year (Miller and Weinstock, 1994; Lewis and Weinstock, 2007).

The large numbers of CSCC in RDEB patients are only matched and exceeded by XP patients. However, clinical observations point to clear differences in pathogenesis of cSCC in $\mathrm{XP}$ and RDEB. Unlike RDEB, metastasis in XP patients is rare. Additionally, $\mathrm{XP}$ have a high rate of internal malignancies such as a 20 -fold increase in incidence of brain tumours, not observed in RDEB (Daya-Grosjean and Sarasin, 2005).

Clinical similarities exist between the cSCCs in both JEB and RDEB patients - multiple cSCCs are common and there is a preponderance of cSCCs in areas of chronic blistering, erosion and scarring in both groups (Fine et al., 2009; Yuen and Jonkman, 2011). These observations point to the possible involvement of a disrupted basement membrane and wounded permissive microenvironment in CSCC carcinogenesis; however, the data are not clear in JEB. Also other blistering and inflammatory skin diseases exist which are not cancer prone. What is clear is that COL7A1 plays an important role in CSCC but the conspicuous absence of cancer in other mucousal tissues such as oral and GI tracts, which can also blister, in RDEB patients and are reported to express COL7A1, is perplexing. Furthermore, although a significant number of studies have been undertaken that seek to explain the high incidence and aggressive nature of cSCC in RDEB patients no single experiment or investigation has provided conclusive answers to these questions and often the data can be conflicting and controversial.

\subsection{Expression of type VII collagen in cancers}

Since the development of reliable monoclonal antibodies (Sakai et al., 1986; Leigh et al., 1988) numerous studies to examine the expression of type VII collagen in a wide range of malignant tissues have been conducted. The resulting data have yielded diverging results, which are summarized in Table 1 and discussed herein. It is apparent that type VII collagen can be differentially expressed in different tumour types. Protein expression is observed in brain tumours (Paulus et al., 1995), female genital tract SCC (Wetzels et al., 1991), oral SCC (Kainulainen et al., 1997) and head and neck SCC (Wetzels et al., 1991; Wetzels et al., 1992b). 
Up-regulation of the protein and/or mRNA is seen in esophageal SCC (Baba et al., 2006; Kita et al., 2009), colorectal carcinoma (Visser et al., 1993; Skovbjerg et al., 2009) and thyroid carcinoma (Lohi et al., 1998). In the case of esophageal SCC, increased expression of COL7A1 mRNA and its corresponding protein is correlated to a poorer five- year survival rate (Baba et al., 2006; Kita et al., 2009), while evidence in colorectal cancer suggests that the upregulation of COL7A1 mRNA and protein is an early event that occurs in both adenomas and carcinoma (Visser et al., 1993; Skovbjerg et al., 2009).

\begin{tabular}{|c|c|c|}
\hline Reference & Tissue & Type VII Expression and Localization \\
\hline $\begin{array}{l}\text { (Paulus et al., } \\
1995)\end{array}$ & $\begin{array}{l}\text { Brain tumours (choroid } \\
\text { plexus papilloma, } \\
\text { pineoblastoma, pituitary } \\
\text { adenoma) }\end{array}$ & Presence of type VII collagen expression \\
\hline $\begin{array}{l}\text { (Wetzels et al., } \\
1991)\end{array}$ & $\begin{array}{l}\text { Lung SCC } \\
\text { Head and Neck SCC } \\
\text { Female genital tract SCC }\end{array}$ & $\begin{array}{l}\text { Expression seen in carcinomas with squamous } \\
\text { differentiation }\end{array}$ \\
\hline $\begin{array}{l}\text { (Kainulainen et } \\
\text { al., 1997) }\end{array}$ & Oral SCC & $\begin{array}{l}\text { Linear staining pattern around tumour and } \\
\text { cytoplasmic staining in large number of } \\
\text { tumours. Some fibroblast-like stromal cells also } \\
\text { stained positive. }\end{array}$ \\
\hline $\begin{array}{l}\text { (Wetzels et al., } \\
\text { 1992b) }\end{array}$ & Head and Neck SCC & $\begin{array}{l}\text { Expression in basement membranes of all } 42 \\
\text { tumours, independent of the tumour grade. } \\
\text { Expression observed in cytoplasm of } 36 \% \text { of } \\
\text { tumour cells. In more than half of the cases, a } \\
\text { stronger staining in the tumour centre was } \\
\text { seen, which weakens towards the tumour } \\
\text { periphery. }\end{array}$ \\
\hline (Lohi et al., 1998) & $\begin{array}{l}\text { Normal thyroid follicular } \\
\text { epithelium, thyroid } \\
\text { carcinoma }\end{array}$ & $\begin{array}{l}\text { Absent from normal thyroid follicular } \\
\text { epithelium } \\
\text { Expression of protein in most thyroid } \\
\text { carcinomas }\end{array}$ \\
\hline $\begin{array}{l}\text { (Visser et al., } \\
1993 \text { ) }\end{array}$ & $\begin{array}{l}\text { Normal mucosa of colon, } \\
\text { adenoma and } \\
\text { adenocarcinoma }\end{array}$ & $\begin{array}{l}\text { No expression in normal mucosa, but } \\
\text { expression is detected in basement membrane } \\
\text { of dysplastic epithelium. A stronger expression } \\
\text { in well and moderately differentiated } \\
\text { carcinoma }\end{array}$ \\
\hline $\begin{array}{l}\text { (Skovbjerg et al., } \\
2009)\end{array}$ & Colorectal cancer & $\begin{array}{l}\text { The COL7A1 mRNA levels were statistically } \\
\text { significantly higher in adenoma and colorectal } \\
\text { cancer tissue as compared to healthy tissues, } \\
\text { indicating that this is an early event in } \\
\text { carcinogenesis }\end{array}$ \\
\hline (Baba et al., 2006) & Esophageal SCC & $\begin{array}{l}\text { Expression of type VII collagen was closely } \\
\text { related to poor prognosis. Cytoplasmic } \\
\text { expression of type VII collagen was detected in } \\
35 \% \text { of the samples. }\end{array}$ \\
\hline
\end{tabular}




\begin{tabular}{|c|c|c|}
\hline (Kita et al., 2009) & Esophageal SCC & $\begin{array}{l}\text { The expression levels COL7A1 mRNA is } \\
\text { higher in malignant tissues than normal tissues } \\
\text { and is significantly correlated with depth of } \\
\text { tumor invasion and lymphatic invasion. } \\
\text { Patients with high levels of COL7A1 mRNA } \\
(\mathrm{n}=4) \text { have a worse five-year survival rate than } \\
\text { otherwise }(\mathrm{n}=22) \text {. }\end{array}$ \\
\hline $\begin{array}{l}\text { (Dumas et al., } \\
\text { 1999) }\end{array}$ & BCC and cSCC & $\begin{array}{l}\text { Expression tends to decrease on the leading } \\
\text { edge of invasive tumor mass in BCC and SCC. } \\
\text { Reduction of type VII collagen expression is } \\
\text { greater in SCC than BCC, when compared to } \\
\text { normal skin }\end{array}$ \\
\hline $\begin{array}{l}\text { (Yasaka et al., } \\
1994)\end{array}$ & BCC & $\begin{array}{l}\text { Reduced staining in the basement membrane } \\
\text { of some nests of BCCs along with intra- } \\
\text { tumoral staining in all tumours }\end{array}$ \\
\hline $\begin{array}{l}\text { (Jones et al., } \\
\text { 1989) }\end{array}$ & BCC & $\begin{array}{l}\text { Localized to the basement membrane zone of } \\
\text { tumor cells and some stromal staining } \\
\text { observed at the tumour stromal interface }\end{array}$ \\
\hline $\begin{array}{l}\text { (Bechetoille et al., } \\
\text { 2000) }\end{array}$ & $\begin{array}{l}\text { Melanoma cell lines } \\
\text { growing on de- } \\
\text { epidermised dermis }\end{array}$ & $\begin{array}{l}\text { Local invasion of human metastatic melanoma } \\
\text { cells through the basement membrane of a de- } \\
\text { epidermised dermis is correlated with } \\
\text { discontinuities of type VII collagen }\end{array}$ \\
\hline $\begin{array}{l}\text { (Kirkham et al., } \\
\text { 1989) }\end{array}$ & Melanoma & $\begin{array}{l}\text { Discontinuities of type VII collagen in the } \\
\text { basement membrane observed in melanomas } \\
\text { thicker than } 0.9 \mathrm{~mm}\end{array}$ \\
\hline (Tani et al., 1996) & $\begin{array}{l}\text { Normal gastric } \\
\text { epithelium } \\
\text { Gastric carcinoma }\end{array}$ & $\begin{array}{l}\text { Punctate expression in basement membrane of } \\
\text { normal surface epithelium. Basement } \\
\text { membrane of most tumors were devoid of type } \\
\text { VII collagen expression, although some } \\
\text { occasional staining is observed at sites } \\
\text { containing laminin-332 }\end{array}$ \\
\hline \begin{tabular}{|l} 
(Nagle et al., \\
1994)
\end{tabular} & Prostate carcinoma & Loss of type VII collagen expression \\
\hline (Bonkhoff, 1998) & Prostate carcinoma & $\begin{array}{l}\text { Early stromal invasion is associated with the } \\
\text { loss of both hemidesmosomal proteins and } \\
\text { type VII collagen but invasive tumor cells then } \\
\text { go on to produce basement membrane-like } \\
\text { matrices }\end{array}$ \\
\hline $\begin{array}{l}\text { (Wetzels et al., } \\
\text { 1992a) }\end{array}$ & Lung Carcinoma & $\begin{array}{l}\text { Expression seen in lung SCCs, with a } \\
\text { corresponding reduction in expression with } \\
\text { decreasing differentiation. } \\
\text { Type VII collagen was not identified in } \\
\text { adenocarcinomas, small cell carcinomas or } \\
\text { carcinoids. }\end{array}$ \\
\hline
\end{tabular}

Table 1. Type vii collagen expression in malignant tissues 
Conversely, down-regulation of the protein and/or mRNA is observed in cSCC (Dumas et al., 1999), melanoma tumours (Kirkham et al., 1989) and cell lines (Bechetoille et al., 2000), lung SCCs (Wetzels et al., 1992a), BCCs (Jones et al., 1989; Yasaka et al., 1994; Dumas et al., 1999), gastric carcinoma (Tani et al., 1996) and prostate carcinoma (Nagle et al., 1994; Bonkhoff, 1998). In prostate carcinogenesis, evidence points to the loss of type VII collagen as an early event which leads to dysplasia, (Bonkhoff, 1998). In addition, anticancer drugs shown to be effective against prostate cancer down-regulate COL7A1 expression in vitro (Hurst et al., 2008). While the lack of type VII collagen in these cancers seems to correlate with dysplasia, the lack of an increased risk of lung, BCC, gastric and prostate cancers in RDEB patients would suggest that the loss of type VII collagen is more likely to be a consequence of tumourigenesis rather than a key driver in the aforementioned cancers.

Interestingly, a weaker staining is observed at the tumour periphery, along with decreased type VII collagen reported in both cutaneous (Dumas et al., 1999) and head and neck SCC (Wetzels et al., 1992b). Local invasion of human metastatic melanoma cells through the basement membrane of a de-epidermised dermis is correlated with discontinuities of type VII collagen staining along basement membrane (Bechetoille et al., 2000). This experiment parallels earlier observations that discontinuities of type VII collagen staining appear when malignant melanomas progress past a thickness of $0.9 \mathrm{~mm}$ (Kirkham et al., 1989).

Cytoplasmic type VII collagen immuno-staining has also been demonstrated in CSCC (Dumas et al., 1999), oral SCC (Kainulainen et al., 1997), and head and neck SCC (Wetzels et al., 1992b). Similar intracellular expression of type VII collagen has been reported in RDEB SCC (Kanitakis et al., 1997) and transiently in wounded normal and RDEB skin (McGrath et al., 1992a), suggesting cytoplasmic type VII collagen may be involved in tumour development and/or wound healing. Cellular signaling via type VII collagen has recently been identified (reviewed by Rodeck and Uitto and discussed in the following section (Rodeck and Uitto, 2007)) and may have considerable impact on the processes of tumorigenesis and wound healing. But overall it is difficult to distill the immunohistochemical and mRNA expression data into any sweeping conclusive statement as to whether aberrant expression of type VII collagen contributes to human cancer and in what way.

\subsection{Search for mechanisms involved in RDEB SCC tumourigenesis}

The mechanism behind the aggressive nature of RDEB SCC has thus far remained elusive. One possibility recently explored was that the chronically wounded environment in RDEB patients may enable HPV infection and contribute toward CSCC tumourigenesis. Research within our lab has found that the aggressive nature of RDEB SCC cannot be accounted for by the overall prevalence of alpha- or beta-HPV infection through demonstrating comparative data for non-RDEB SCC (Purdie et al., 2010). As discussed in the introduction, various independent studies conducted thus far have revealed heterogeneity in the incidence of RAS mutations in human CSCC and we have been unable to detect RAS mutations in six RDEB SCC patients and four non-RDEB SCC patient samples (Pourreyron et al., 2007). Similar to non-RDEB SCC data a proportion of RDEB tumours harbour TP53 mutation and CDKN2A methylation/ aberrant expression (Arbiser et al., 2004; Watt et al., 2011). In the following section we discuss the various ideas and studies investigating aspects of RDEB and RDEB SCC pathology.

\section{Tumours - wounds that do not heal}

Given the constantly wounded environment in RDEB, parallels can be drawn between RDEB SCC and Marjolin's ulcers. Marjolin's ulcer refers to a malignant lesion that arises in areas of 
chronic inflammation such as burns and ulcers. A retrospective study of 412 case reports between 1923 and 2004 on Marjolin's ulcers found cSCC to be the most frequent cancer at 71\%, followed by BCC at $21 \%$ and melanoma at $6 \%$ (Kowal-Vern and Criswell, 2005). The cSCCs tended to be aggressive - local recurrence, regional lymph node metastases and distant metastases were found in $16 \%, 22 \%$ and $14 \%$ of the cases respectively and the mortality rate was $21 \%$. In Marjolin's ulcer, the mean latency period is 31 years while almost $50 \%$ of sg-RDEB patients develop their first cSCC at the age of 30 (Fine et al., 2009). Both Marjolin's Ulcers and RDEB SCCs are much more aggressive than UV-induced CSCC from the general population. Certainly this clinical parallel exists and is yet to be fully explored.

\section{Tissue stress and "activated" keratinocytes}

Goldberg and colleagues postulated that repetitive tissue stress could be the underlying driving force for tumour promotion in RDEB where there is an altered interaction of keratinocytes with their chronically stressed microenvironment (Goldberg et al., 1988). In support of this theory, Smoller et al. found a "growth-activated" state characterized by upregulation of filaggrin, involucrin and specific cytokeratins in biopsies taken from RDEB healed wounds $(n=6)$ and in all actinic keratoses $(n=10)$ (Smoller et al., 1990a; Smoller et al., 1990b). In contrast, healed wounds of the simplex form of epidermolysis bullosa (Barkan et al., 2010), which usually heal without scarring and are not predisposed to CSCC, did not exhibit this "activated" state $(n=4)$. These observations lead the investigators to speculate that this growth activation could be a reason for cSCC development.

\section{Contribution of type VII collagen to RDEB SCC tumourigenesis}

Given the inverse relationship between severity of DEB and type VII collagen expression (McGrath et al., 1993), it has long been hypothesized that the absence of type VII collagen in RDEB patients is a major contributing factor to the aggressive nature of SCC. However, given the absence of significant CSCC incidence in DDEB patients (Fine et al., 2009) and no reports of unaffected RDEB family members developing CSCC, little evidence exists for COL7A1 being a classical tumour suppressor gene. A number of studies have investigated COL7A1 and type VII collagen manipulation in different experimental systems.

Chen and colleagues observed that re-expression of full-length type VII collagen into RDEB keratinocytes and RDEB fibroblasts using lentivirus resulted in reduced cell migration and increased cell adhesion (Chen et al., 2002). Subsequently, intravenous injection of RDEB fibroblasts re-expressing type VII collagen into athymic mice led to improved wound healing compared to non-gene corrected RDEB fibroblasts (Woodley et al., 2007). Following this and at odds with the data in RDEB patient cells, it was shown that type VII collagen increased migration in normal keratinocytes and fibroblasts, identifying that a 684 amino acid residue within the triple helical domain of type VII collagen conferred this increase (Chen et al., 2008). These data suggest that the ability of type VII collagen to influence migration and adhesion is dependent on the cellular context and possibly the status of endogenous COL7A1.

Martins and colleagues knocked-down expression of type VII collagen in non-RDEB SCC keratinocytes in vitro and showed that loss of type VII collagen promoted migration and invasion, increased epithelial mesenchymal transition (EMT) and reduced terminal epithelial differentiation, characteristics usually associated with tumourigenesis (Martins et al., 2009). This work agrees with the data demonstrating decreased migration in RDEB cells upon reintroduction of wild type COL7A1 and may suggest similarities between RDEB nontumour cells and non-RDEB tumour cells. 
Ortiz-Urda and colleagues demonstrated that type VII collagen, specifically the NC1 domain, was required for RAS-driven tumourigenesis in a model where primary keratinocytes are transformed with oncogenic RAS-V12 and the NF-kB super-repressor IкB $\alpha \mathrm{M}$ (Ortiz-Urda et al., 2005). Injection of transformed RDEB cells without detectable type VII collagen did not grow quickly as tumours in mice, whereas those expressing NC1 fragment grew rapidly. The fibronectin-like sequences within the NC1 domain have multiple functions and facilitate binding to laminin beta3 domain V-III to not only activate phosphoinositol-3-kinase signaling, but also promote tumor cell invasion, prevent apoptosis and promote neoplasia (Waterman et al., 2007). These results suggested that RDEB patients who still express the NC1 domain may be more susceptible to developing CSCC, while conversely, sg-RDEB patients without any detectable type VII collagen expression will be less likely to develop cSCC. However, it has been demonstrated that RDEB patients without any detectable type VII collagen can still develop cSCCs (Pourreyron et al., 2007; Rodeck and Uitto, 2007).

The above studies highlight the importance of type VII collagen in tumourigenesis but also suggest that cellular context is important in how type VII collagen exerts its influence. It is clear that, regardless of the amount and type of mutated type VII collagen expressed, cSCC will develop in RDEB patients.

\section{Immune surveillance in RDEB}

As discussed earlier, avoidance of immune destruction is a recognized hallmark of cancer which can enable growth and dissemination (Hanahan and Weinberg, 2011). In the only study of its kind to date, natural killer cell activity was observed to be reduced in RDEB, DDEB, JEB and malabsorption patients but not in EBS and normal patients (Tyring et al., 1989), which the authors suggest may be responsible for the development of CSCC in RDEB patients.

\section{Basic fibroblast growth factor in RDEB}

Elevated levels of urinary basic fibroblast growth factor (bFGF) were observed in more than $51 \%$ of 39 RDEB patients, $21 \%$ of 33 unaffected family members and $13 \%$ of 30 EBS patients also had elevated levels (Arbiser et al., 1998). It is only in JEB that elevated bFGF levels were not observed in this study. Although the authors postulate that bFGF might promote tumourigenesis through its mitogenic or angiogenic effect, the presence of elevated levels in unaffected family members would suggest other confounding factors may determine bFGF levels. Furthermore, no direct correlation was found between the levels of bFGF to the presence of CSCC in RDEB patients.

\section{Matrix metalloproteinase expression in RDEB}

During wound healing, matrix metalloproteinase (MMPs) play a vital role in cell migration, tissue remodeling and inflammation (Gill and Parks, 2008). Given the constant wounded environment in RDEB, there have been reports of elevated levels of MMPs in the fragile skin (Bodemer et al., 2003; Bruckner-Tuderman et al., 1992; Sato et al., 1995). MMP1 gene, which encodes a type VII collagen degrading enzyme, has recently emerged as being a modifier gene involved in RDEB. A single nucleotide polymorphism in MMP1 promoter increased expression of MMP1 protein (Titeux et al., 2008). This increased expression of MMP1 resulted in a faster degradation of type VII collagen, and a worse disease severity in RDEB patients. How this modifier gene relates to the development of cSCC in RDEB patients is yet to be determined. While the presence of this modifier gene may provide an explanation for 
the phenotypic variation observed in some DEB patients with the same COL7A1 mutations, it is unlikely to be the sole modifier. In support of this notion, recent observations by a separate group did not find a correlation between RDEB disease severity and MMP1 genotype (Kern et al., 2009).

MMP protein expression has been investigated in RDEB CSCC: MMP-7 protein levels were detected in both RDEB SCC ( 25 of 25 samples) and UV induced cSCC (60 of 61 samples) but only detected in 1 of 27 normal skin samples (Kivisaari et al., 2008). The intensity of MMP-7 immunostaining was correlated significantly and positively with the histological grade of RDEB SCC tumour, which was not observed in sporadic UV-induced cSCC. Specific knockdown of MMP-7 using RNAi in cSCC cell-lines inhibits shedding of heparin-binding epidermal growth factor-like growth factor (HB-EGF), resulting in attenuation of EGF signalling and reduced cell proliferation (Kivisaari et al., 2010). Another cSCC specific marker, which has been suggested to be involved in RDEB tumourigenesis, is mucin-1. This marker is found in all RDEB SCCs $(n=25)$, JEB SCC $(n=5)$ and 52 of 55 UV induced cSCCs (Cooper et al., 2004).

\section{IGFB3 and RDEB SCC}

Gene expression profiling was studied using microarray comparing RDEB SCC $(n=3)$ and non-RDEB SCC tissue $(n=3)$ with the corresponding peri-tumoural skin found decreased expression of death-associated kinase-3 and insulin-like growth factor-binding protein-3 (IGFBP-3) genes in RDEB SCC compared to non-RDEB SCC (Mallipeddi et al., 2004). In particular, the reduced expression of IGFBP-3 was confirmed using semi-quantitative RTPCR, real-time PCR and immunohistochemistry. The authors speculate that the diminished levels of IGFBP result in reduced tumour cell apoptosis by allowing cSCC to grow unchecked. However, further work has yet to demonstrate the biological implications of reduced levels of IGFBP in RDEB SCC development. It is also important to note that overall there were very few differences between RDEB and non-RDEB SCC expression profiles in this experiment (Mallipeddi et al., 2004).

\section{Are there differences between RDEB SCC and non-RDEB SCC?}

The clinical data would suggest defined pathology unique to RDEB SCC yet numerous molecular and histological studies identify only similarities with UV induced cSCC in the general population (Tyring et al., 1989; Arbiser et al., 1998; Arbiser et al., 2004; Cooper et al., 2004; Mallipeddi et al., 2004; Kivisaari et al., 2008; Purdie et al., 2010) and those which report differences are neither replicated nor significantly powered to make definitive conclusions (Mallipeddi et al., 2004; Ortiz-Urda et al., 2005). To date no single study has identified a distinct difference in the histology or expression of markers both at the mRNA or protein level when comparing cSCC from RDEB patients with cSCC in the general population. We have recently tried to address this question with a gene expression study utilising microarrays containing more than 47,000 probes to interrogate RNA isolated from primary cSCC keratinocytes isolated from RDEB and non-RDEB patients (Watt et al., 2011). Disappointingly, yet consistent with previous studies, no significant differences between the tumour groups were identified: unsupervised clustering of this array data demonstrated lack of separation between RDEB and non-RDEB CSCC samples (Fig. 1). However, the dendrogram was able to clearly separate non-cSCC (NHK and EBK) from cSCC (SCC and RDEB SCC) keratinocytes, and further interrogation of this data has identified markers common to all cSCC which have potential for development as therapeutic targets in RDEB 
SCC (Watt et al., 2011). Overall, this data suggests that the aggressive nature of RDEB SCC may not be accounted for by differences in the tumour keratinocytes.

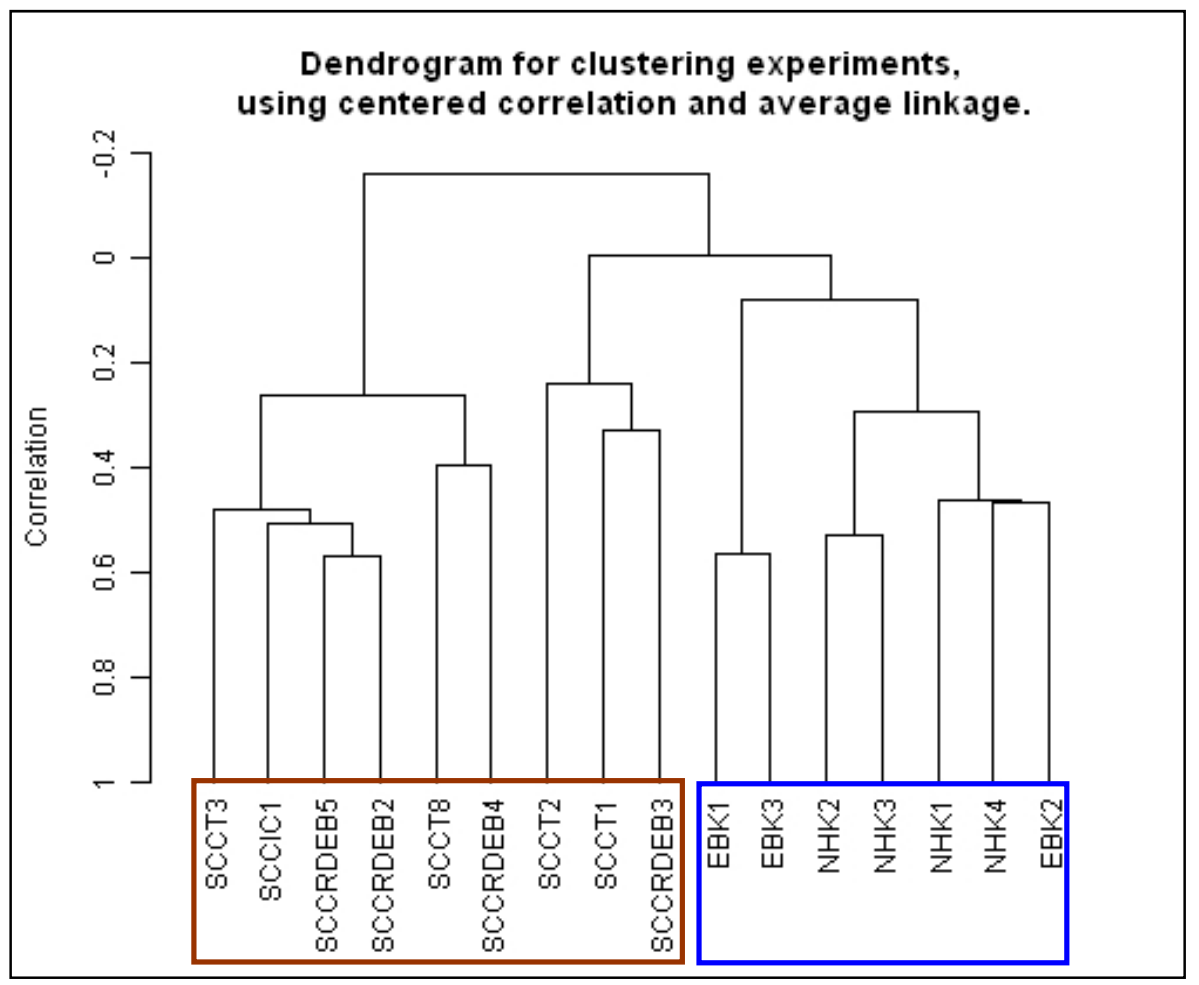

Fig. 1. Unsupervised clustering of in vitro keratinocyte gene expression data separates tumour from normal but is unable to distinguish RDEB cSCC from non-RDEB cSCC. Although cSCC keratinocyte samples (red box) cluster independently of non-cSCC keratinocyte samples (blue box), no clear separation of RDEB SCC and non-RDEB SCC keratinocytes is found. $\mathrm{NHK}=$ normal skin samples, $\mathrm{EB}=$ cells isolated from RDEB skin, SCC $=$ UV-induced cSCC. SCCRDEB $=$ cSCC from RDEB patient (adapted from Watt et al., 2011).

\subsection{RDEB SCC and the tumour microenvironment}

Increasing evidence now points to the dermal component as being a major factor in wound healing and CSCC invasion in non-RDEB individuals (Gaggioli et al., 2007; Erez et al., 2010). In particular, fibroblasts have been shown to play a role in cancer initiation and progression via stromal-epithelial interactions (Bhowmick et al., 2004). They can provide oncogenic signals such as fibroblast growth factors, which act in a paracrine manner to the transformed tumour keratinocytes. These stromal cells are said to be "activated", becoming more proliferative and secreting more ECM proteins like type I collagen and fibronectin. Such fibroblasts are also known as cancer-associated fibroblasts (CAF) (Kalluri and Zeisberg, 2006). 
The observation that little differences were observed between RDEB tumour and non-RDEB tumour keratinocytes, and in the light of recent recognition of the importance of the tumour microenvironment prompted us to investigate the other major type VII collagen secreting cell type of the surrounding stroma in RDEB skin and RDEB SCC - the dermal fibroblasts (Marinkovich et al., 1993; Goto et al., 2006).

To study this, we have undertaken gene expression profiling comparing cultured primary human dermal fibroblasts isolated from reduction surgery samples (normal), RDEB skin from patients yet to be diagnosed with cSCC, cSCC tumours arising in the general population and those from RDEB patients. Preliminary results are promising. Based on the microarray data, RDEB and CSCC fibroblasts share similar gene expression profile in culture and that the RDEB SCC fibroblasts are most dysregulated at the mRNA level out of all three disease states compared to normal fibroblasts ( $\mathrm{Ng}$ et al., 2010). These data suggests that the dermal microenvironment may be conducive to tumourigenesis and that transformation of RDEB to RDEB cSCC fibroblast may be crucial in accounting for the aggressive nature of cSCCs in RDEB patients.

\subsection{Future directions in RDEB SCC}

At present there is no cure for RDEB. However, several molecular therapies, which aim to correct EB, are currently undergoing clinical trials. One of the most promising therapies for RDEB patients is bone marrow transplantation. Following normal donor marrow-derived cells injection in murine COL7A1(-/-) models, successful re-expression of type VII collagen forming rudimentary anchoring fibrils and reduced blister formation was observed in the skin (Tolar et al., 2009). These positive results prompted human clinical trials involving bone marrow transplant therapy in RDEB patients. The latest published clinical trial results are encouraging (Wagner et al., 2010). Six out of seven children underwent successful transplantation after which they experienced improved wound healing and reduced blister formation between 30-130 days post transplantation, increased type VII collagen deposition and a sustained presence of donor cells in their skin. One patient died about 6 months posttransplantation as a consequence of graft rejection and infection. Hence, while this approach holds much promise, it is not without its inherent risks. Furthermore, immune-suppression in solid organ transplant patients has been linked to a high risk for developing skin cancer. Given that RDEB patients are already predisposed to develop cSCC, it remains to be seen if immunosuppression in the RDEB patients undergoing bone marrow transplantation will further accelerate cSCC development or whether improving the clinical condition will result in a reduction in $\mathrm{CSCC}$ incidence.

\section{Conclusion}

While most efforts and funding have been directed towards understanding the complex nature of skin cancer in the general population, sometimes it is through the study of the rare genetic disorders, such as xeroderma pigmentosum and RDEB, which offers insights into the biology of cSCC tumourigenesis by virtue of their known genetic mutation(s) leading to a specific phenotype. Through the study of $\mathrm{XP}$, we know the importance of DNA repair in correcting UV damage in the skin. In the case of RDEB, the reasons for the development of numerous life-threatening cSCCs are still not fully elucidated, but evidence points towards a role for a permissive tumour microenvironment. 


\section{References}

Agrawal N, Frederick MJ, Pickering CR, Bettegowda C, Chang K, Li RJ, et al. (2011) Exome sequencing of head and neck squamous cell carcinoma reveals inactivating mutations in NOTCH1. Science Epub 2011 Jul 28. doi: 10.1126/science.1206923.

Alter BP (2003) Cancer in Fanconi anemia, 1927-2001. Cancer 97:425-440.

Alter BP, Olson SB (2009) Wilms tumor, AML, and medulloblastoma in a child with cancer prone syndrome of total premature chromatid separation and Fanconi anemia. Pediatr Blood Cancer 54:488; author reply 489.

Arbiser JL, Fine JD, Murrell D, Paller A, Connors S, Keough K, et al. (1998) Basic fibroblast growth factor: a missing link between collagen VII, increased collagenase, and squamous cell carcinoma in recessive dystrophic epidermolysis bullosa. Mol Med 4:191-195.

Arbiser JL, Fan CY, Su X, Van Emburgh BO, Cerimele F, Miller MS, et al. (2004) Involvement of p53 and p16 tumor suppressor genes in recessive dystrophic epidermolysis bullosa-associated squamous cell carcinoma. J Invest Dermatol 123:788-790.

Arita K, Wessagowit V, Inamadar AC, Palit A, Fassihi H, Lai-Cheong JE, et al. (2007) Unusual molecular findings in Kindler syndrome. Br J Dermatol 157:1252-1256.

Arnault JP, Wechsler J, Escudier B, Spatz A, Tomasic G, Sibaud V, et al. (2009) Keratoacanthomas and squamous cell carcinomas in patients receiving sorafenib. $J$ Clin Oncol 27:e59-61.

Arron ST, Ruby JG, Dybbro E, Ganem D, Derisi JL (2011) Transcriptome sequencing demonstrates that human papillomavirus is not active in cutaneous squamous cell carcinoma. J Invest Dermatol 131:1745-1753.

Ashton GH, McLean WH, South AP, Oyama N, Smith FJ, Al-Suwaid R, et al. (2004) Recurrent mutations in kindlin-1, a novel keratinocyte focal contact protein, in the autosomal recessive skin fragility and photosensitivity disorder, Kindler syndrome. J Invest Dermatol 122:78-83.

Astori G, Lavergne D, Benton C, Hockmayr B, Egawa K, Garbe C, et al. (1998) Human Papillomaviruses are Commonly Found in Normal Skin of Immunocompetent Hosts. J Invest Dermatol 110:752-755.

Baba Y, Iyama K, Honda S, Ishikawa S, Miyanari N, Baba H (2006) Cytoplasmic expression of type VII collagen is related to prognosis in patients with esophageal squamous cell carcinoma. Oncology 71:221-228.

Bagby GC, Jr. (2003) Genetic basis of Fanconi anemia. Curr Opin Hematol 10:68-76.

Bagby GC, Alter BP (2006) Fanconi anemia. Semin Hematol 43:147-156.

Balmain A, Ramsden M, Bowden GT, Smith J (1984) Activation of the mouse cellular Harvey-ras gene in chemically induced benign skin papillomas. Nature 307:658-660.

Barkan D, El Touny LH, Michalowski AM, Smith JA, Chu I, Davis AS, et al. (2010) Metastatic growth from dormant cells induced by a col-I-enriched fibrotic environment. Cancer Res 70:5706-5716.

Bazex A, Griffiths A (1980) Acrokeratosis paraneoplastica--a new cutaneous marker of malignancy. Br J Dermatol 103:301-306.

Bechetoille N, Haftek M, Staquet MJ, Cochran AJ, Schmitt D, Berthier-Vergnes O (2000) Penetration of human metastatic melanoma cells through an authentic dermalepidermal junction is associated with dissolution of native collagen types IV and VII. Melanoma Res 10:427-434. 
Benjamin CL, Ananthaswamy HN (2007) p53 and the pathogenesis of skin cancer. Toxicol Appl Pharmacol 224:241-248.

Bhowmick NA, Chytil A, Plieth D, Gorska AE, Dumont N, Shappell S, et al. (2004) TGF-beta signaling in fibroblasts modulates the oncogenic potential of adjacent epithelia. Science 303:848-851.

Blumenthal GM, Dennis PA (2008) PTEN hamartoma tumor syndromes. Eur J Hum Genet 16:1289-1300.

Bodemer C, Tchen SI, Ghomrasseni S, Seguier S, Gaultier F, Fraitag S, et al. (2003) Skin expression of metalloproteinases and tissue inhibitor of metalloproteinases in sibling patients with recessive dystrophic epidermolysis and intrafamilial phenotypic variation. J Invest Dermatol 121:273-279.

Bonkhoff H (1998) Analytical molecular pathology of epithelial-stromal interactions in the normal and neoplastic prostate. Anal Quant Cytol Histol 20:437-442.

Borg MF, Olver IN, Hill MP (1998) Rothmund-Thomson syndrome and tolerance of chemoradiotherapy. Australas Radiol 42:216-218.

Boukamp P, Stanbridge EJ, Foo DY, Cerutti PA, Fusenig NE (1990) c-Ha-ras oncogene expression in immortalized human keratinocytes (HaCaT) alters growth potential in vivo but lacks correlation with malignancy. Cancer Res 50:2840-2847.

Brash DE, Rudolph JA, Simon JA, Lin A, McKenna GJ, Baden HP, et al. (1991) A role for sunlight in skin cancer: UV-induced p53 mutations in squamous cell carcinoma. Proc Natl Acad Sci U S A 88:10124-10128.

Brown VL, Harwood CA, Crook T, Cronin JG, Kelsell DP, Proby CM (2004) p16INK4a and p14ARF tumor suppressor genes are commonly inactivated in cutaneous squamous cell carcinoma. J Invest Dermatol 122:1284-1292.

Bruckner-Tuderman L, Winberg JO, Anton-Lamprecht I, Schnyder UW, Gedde-Dahl T, Jr. (1992) Anchoring fibrils, collagen VII, and neutral metalloproteases in recessive dystrophic epidermolysis bullosa inversa. J Invest Dermatol 99:550-558.

Bruckner-Tuderman L (2001) Dermal-epidermal adhesion. In: Cell adhesion and migration in skin disease (Barker J, McGrath J, eds), Amsterdam: Harwood Academic Publishers, 133-163.

Burgeson RE (1993) Type VII collagen, anchoring fibrils, and epidermolysis bullosa. J Invest Dermatol 101:252-255.

Byrne CR (2006) The focal nature of Darier's disease lesions: calcium pumps, stress, and mutation? J Invest Dermatol 126:702-703.

Campbell C, Quinn AG, Ro YS, Angus B, Rees JL (1993) p53 mutations are common and early events that precede tumor invasion in squamous cell neoplasia of the skin. $J$ Invest Dermatol 100:746-748.

Chen M, Kasahara N, Keene DR, Chan L, Hoeffler WK, Finlay D, et al. (2002) Restoration of type VII collagen expression and function in dystrophic epidermolysis bullosa. Nat Genet 32:670-675.

Chen M, Hou Y, Wang X, Martin S, Li W, Woodley D (2008) A 684 helical domain of type VII collagen promotes in vivo skin wound closure by enhancing fibroblast and keratinocyte migration [Abstract]. J Invest Dermatol 128:S48.

Chorny JA, Shroyer KR, Golitz LE (1993) Malignant melanoma and a squamous cell carcinoma in recessive dystrophic epidermolysis bullosa. Arch Dermatol 129:1212. 
Christiano AM, Anhalt G, Gibbons S, Bauer EA, Uitto J (1994) Premature termination codons in the type VII collagen gene (COL7A1) underlie severe, mutilating recessive dystrophic epidermolysis bullosa. Genomics 21:160-168.

Christiano AM, Uitto J (1996) Molecular complexity of the cutaneous basement membrane zone. Revelations from the paradigms of epidermolysis bullosa. Exp Dermatol 5:111.

Christiano AM, Amano S, Eichenfield LF, Burgeson RE, Uitto J (1997) Premature termination codon mutations in the type VII collagen gene in recessive dystrophic epidermolysis bullosa result in nonsense-mediated mRNA decay and absence of functional protein. J Invest Dermatol 109:390-394.

Christiano AM, Crollick J, Pincus S, Uitto J (1999) Squamous cell carcinoma in a family with dominant dystrophic epidermolysis bullosa: a molecular genetic study. Exp Dermatol 8:146-152.

Conrado LA, Marques SA, Lastoria JC, Cuce LC, Marques ME, Dillon NL (2007) Keratitisichthyosis-deafness (KID) syndrome with squamous cell carcinoma. Int J Dermatol 46:403-406.

Cooper HL, Cook IS, Theaker JM, Mallipeddi R, McGrath J, Friedmann P, et al. (2004) Expression and glycosylation of MUC1 in epidermolysis bullosa-associated and sporadic cutaneous squamous cell carcinomas. Br J Dermatol 151:540-545.

CRUK (2011a) CancerStats report: Incidence 2008 UK [Online] Available from: http://info.cancerresearchuk.org/prod_consump/groups/cr_common/@nre/@st a/documents/generalcontent/cr_072111.pdf (Accessed June 2011).

CRUK (2011b) Latest UK cancer incidence year and mortality year summary - age standardised rates [Online] Available from:

http://info.cancerresearchuk.org/prod_consump/groups/cr_common/@nre/@st a/documents/generalcontent/cr_072108.pdf (Accessed June 2011).

Dajee M, Lazarov M, Zhang JY, Cai T, Green CL, Russell AJ, et al. (2003) NF-kappaB blockade and oncogenic Ras trigger invasive human epidermal neoplasia. Nature 421:639-643.

Daya-Grosjean L, Robert C, Drougard C, Suarez H, Sarasin A (1993) High mutation frequency in ras genes of skin tumors isolated from DNA repair deficient xeroderma pigmentosum patients. Cancer Res 53:1625-1629.

Daya-Grosjean L, Sarasin A (2005) The role of UV induced lesions in skin carcinogenesis: an overview of oncogene and tumor suppressor gene modifications in xeroderma pigmentosum skin tumors. Mutat Res 571:43-56.

de Oliveira WR, Festa Neto C, Rady PL, Tyring SK (2003) Clinical aspects of epidermodysplasia verruciformis. J Eur Acad Dermatol Venereol 17:394-398.

Dhitavat J, Fairclough RJ, Hovnanian A, Burge SM (2004) Calcium pumps and keratinocytes: lessons from Darier's disease and Hailey-Hailey disease. Br J Dermatol 150:821-828.

Downs AM, Ward KA, Peachey RD (1997) Subungual squamous cell carcinoma in Darier's disease. Clin Exp Dermatol 22:277-279.

Dumas V, Kanitakis J, Charvat S, Euvrard S, Faure M, Claudy A (1999) Expression of basement membrane antigens and matrix metalloproteinases 2 and 9 in cutaneous basal and squamous cell carcinomas. Anticancer Res 19:2929-2938. 
Durinck S, Ho C, Wang NJ, Liao W, Jakkula LR, Collisson EA, et al. (2011) Temporal dissection of tumorigenesis in primary cancers. Cancer Discovery Epub 2011 June 29. doi: 10.1158/2159-8290.cd-11-0028

Eady RAJ, Fine J-D, Burge SM (2004) Genetic blistering diseases. In: Rook's textbook of dermatology (Burns T, Breathnach S, Cox N, Griffiths C, eds) 7th ed., Vol. 2, Oxford: Wiley-Blackwell.

Ellis NA, Groden J, Ye TZ, Straughen J, Lennon DJ, Ciocci S, et al. (1995) The Bloom's syndrome gene product is homologous to RecQ helicases. Cell 83:655-666.

Emanuel PO, Rudikoff D, Phelps RG (2006) Aggressive squamous cell carcinoma in Kindler syndrome. Skinmed 5:305-307.

Epstein E, Sr. (1984) Metastases of sun-induced SCC. J Dermatol Surg Oncol 10:418.

Epstein EH (2008) Basal cell carcinomas: attack of the hedgehog. Nat Rev Cancer 8:743-754.

Erez N, Truitt M, Olson P, Hanahan D (2010) Cancer-associated fibroblasts are activated in incipient neoplasia to orchestrate tumor-promoting inflammation in an NFkappaB- dependent manner. Cancer Cell 17:135-147.

Euvrard S, Kanitakis J, Claudy A (2003) Skin cancers after organ transplantation. N Engl J Med 348:1681-1691.

Ferguson-Smith MA, Wallace DC, James ZH, Renwick JH (1971) Multiple self-healing squamous epithelioma. Birth Defects Orig Artic Ser 7:157-163.

Fine J-D (1999) The classification of inherited epidermolysis bullosa. In: Epidermolysis bullosa: clinical, epidemiologic and laboratory advances and the findings of the national epidermolysis bullosa registry (Fine J-D, Bauer E, McGuire J, Moshell A, eds), Baltimore: The Johns Hopkins University Press., 20-47.

Fine J-D, Johnson LB, Suchindran C, Moshell A, Jr TG-D (1999) The epidemology of inherited epidermolysis bullosa: Findings in U.S., Canadian and European Study Populations. In: Epidermolysis bullosa: clinical, epidemiologic and laboratory advances and the findings of the national epidermolysis bullosa registry (Fine J-D, Bauer E, McGuire J, Moshell A, eds), Baltimore: The Johns Hopkins University Press., 101113.

Fine J-D, Eady RAJ, Bauer EA, Bauer JW, Bruckner-Tuderman L, Heagerty A, et al. (2008) The classification of inherited epidermolysis bullosa (EB): Report of the Third International Consensus Meeting on Diagnosis and Classification of EB. J Am Acad Dermatol 58:931-950.

Fine JD, Johnson LB, Weiner M, Li KP, Suchindran C (2009) Epidermolysis bullosa and the risk of life-threatening cancers: the National EB Registry experience, 1986-2006. J Am Acad Dermatol 60:203-211.

Fine JD, Mellerio JE (2009) Extracutaneous manifestations and complications of inherited epidermolysis bullosa: part I. Epithelial associated tissues. J Am Acad Dermatol 61:367-384.

Flaherty K, Puzanov I, Sosman J (2009) Phase I study of PLX4032: proof of concept for V600E BRAF mutation as a therapeutic target in human cancer [Abstract]. J Clin Oncol 27:155.

Gaggioli C, Hooper S, Hidalgo-Carcedo C, Grosse R, Marshall JF, Harrington K, et al. (2007) Fibroblast-led collective invasion of carcinoma cells with differing roles for RhoGTPases in leading and following cells. Nat Cell Biol 9:1392-1400. 
German J (1997) Bloom's syndrome. XX. The first 100 cancers. Cancer Genet Cytogenet 93:100106.

German J, Sanz MM, Ciocci S, Ye TZ, Ellis NA (2007) Syndrome-causing mutations of the BLM gene in persons in the Bloom's Syndrome Registry. Hum Mutat 28:743-753.

Gill SE, Parks WC (2008) Metalloproteinases and their inhibitors: regulators of wound healing. Int J Biochem Cell Biol 40:1334-1347.

Goldberg GI, Eisen AZ, Bauer EA (1988) Tissue stress and tumor promotion. Possible relevance to epidermolysis bullosa. Arch Dermatol 124:737-741.

Goldstein AM, Liu L, Shennan MG, Hogg D, Tucker MA, Struewing JP (2001) A common founder for the V126D CDKN2A mutation in seven North American melanomaprone families. Br J Cancer 85:527-530.

Goto M, Sawamura D, Ito K, Abe M, Nishie W, Sakai K, et al. (2006) Fibroblasts show more potential as target cells than keratinocytes in COL7A1 gene therapy of dystrophic epidermolysis bullosa. J Invest Dermatol 126:766-772.

Goudie DR, D'Alessandro M, Merriman B, Lee H, Szeverenyi I, Avery S, et al. (2011) Multiple self-healing squamous epithelioma is caused by a disease-specific spectrum of mutations in TGFBR1. Nat Genet 43:365-369.

Green CL, Khavari PA (2004) Targets for molecular therapy of skin cancer. Semin Cancer Biol 14:63-69.

Gul U, Kilic A, Gonul M, Cakmak SK, Bayis SS (2007) Clinical aspects of epidermodysplasia verruciformis and review of the literature. Int J Dermatol 46:1069-1072.

Hall JM, Lee MK, Newman B, Morrow JE, Anderson LA, Huey B, et al. (1990) Linkage of early-onset familial breast cancer to chromosome 17q21. Science 250:1684-1689.

Hamm H, Traupe H, Brocker EB, Schubert H, Kolde G (1996) The scleroatrophic syndrome of Huriez: a cancer-prone genodermatosis. Br J Dermatol 134:512-518.

Hanahan D, Weinberg RA (2000) The hallmarks of cancer. Cell 100:57-70.

Hanahan D, Weinberg RA (2011) Hallmarks of cancer: the next generation. Cell 144:646-674.

Haneke E, Gutschmidt E (1979) Premature multiple Bowen's disease in poikiloderma congenitale with warty hyperkeratoses. Dermatologica 158:384-388.

Hara M, Hunayama M, Aiba S, Suetake T, Watanabe M, Tanaka M, et al. (1995) Acrokeratosis paraneoplastica (Bazex syndrome) associated with primary cutaneous squamous cell carcinoma of the lower leg, vitiligo and alopecia areata. Br J Dermatol 133:121-124.

Hartevelt MM, Bavinck JN, Kootte AM, Vermeer BJ, Vandenbroucke JP (1990) Incidence of skin cancer after renal transplantation in The Netherlands. Transplantation 49:506509.

Harwood CA, Proby CM (2002) Human papillomaviruses and non-melanoma skin cancer. Current Opinion in Infectious Diseases 15:101-114.

Heidorn SJ, Milagre C, Whittaker S, Nourry A, Niculescu-Duvas I, Dhomen N, et al. (2010) Kinase-dead BRAF and oncogenic RAS cooperate to drive tumor progression through CRAF. Cell 140:209-221.

Hemel D, Domchek SM (2010) Breast cancer predisposition syndromes. Hematol Oncol Clin North Am 24:799-814.

Hovnanian A, Duquesnoy P, Blanchet-Bardon C, Knowlton RG, Amselem S, Lathrop M, et al. (1992) Genetic linkage of recessive dystrophic epidermolysis bullosa to the type VII collagen gene. J Clin Invest 90:1032-1036. 
Howlett NG, Taniguchi T, Olson S, Cox B, Waisfisz Q, De Die-Smulders C, et al. (2002) Biallelic inactivation of BRCA2 in Fanconi anemia. Science 297:606-609.

Huang S, Lee L, Hanson NB, Lenaerts C, Hoehn H, Poot M, et al. (2006) The spectrum of WRN mutations in Werner syndrome patients. Hum Mutat 27:558-567.

Hurst R, Elliott RM, Goldson AJ, Fairweather-Tait SJ (2008) Se-methylselenocysteine alters collagen gene and protein expression in human prostate cells. Cancer Letter 269:117126.

Jin Y, Martins C, Jin C, Salemark L, Jonsson N, Persson B, et al. (1999) Nonrandom karyotypic features in squamous cell carcinomas of the skin. Genes Chromosomes Cancer 26:295-303.

Johnson RL, Rothman AL, Xie J, Goodrich LV, Bare JW, Bonifas JM, et al. (1996) Human homolog of patched, a candidate gene for the basal cell nevus syndrome. Science 272:1668-1671.

Jones JC, Steinman HK, Goldsmith BA (1989) Hemidesmosomes, collagen VII, and intermediate filaments in basal cell carcinoma. J Invest Dermatol 93:662-671.

Kainulainen T, Grenman R, Oikarinen A, Greenspan DS, Salo T (1997) Distribution and synthesis of type VII collagen in oral squamous cell carcinoma. J Oral Pathol Med 26:414-418.

Kalluri R, Zeisberg M (2006) Fibroblasts in cancer. Nat Rev Cancer 6:392-401.

Kanitakis J, Barthelemy H, Faure M, Claudy A (1997) Intracellular expression of type VII collagen in squamous cell carcinoma complicating dystrophic epidermolysis bullosa. Br J Dermatol 137:310-313.

Kaspar TA, Wagner RF, Jr., Jablonska S, Niimura M, Tyring SK (1991) Prognosis and treatment of advanced squamous cell carcinoma secondary to epidermodysplasia verruciformis: a worldwide analysis of 11 patients. J Dermatol Surg Oncol 17:237240.

Kern JS, Gruninger G, Imsak R, Muller ML, Schumann H, Kiritsi D, et al. (2009) Forty-two novel COL7A1 mutations and the role of a frequent single nucleotide polymorphism in the MMP1 promoter in modulation of disease severity in a large European dystrophic epidermolysis bullosa cohort. Br J Dermatol 161:1089-1097.

Kirkham N, Price ML, Gibson B, Leigh IM, Coburn P, Darley CR (1989) Type VII collagen antibody LH 7.2 identifies basement membrane characteristics of thin malignant melanomas. J Pathol 157:243-247.

Kita Y, Mimori K, Tanaka F, Matsumoto T, Haraguchi N, Ishikawa K, et al. (2009) Clinical significance of LAMB3 and COL7A1 mRNA in esophageal squamous cell carcinoma. Eur J Surg Oncol 35:52-58.

Kitao S, Shimamoto A, Goto M, Miller RW, Smithson WA, Lindor NM, et al. (1999) Mutations in RECQL4 cause a subset of cases of Rothmund-Thomson syndrome. Nat Genet 22:82-84.

Kivirikko S, McGrath JA, Baudoin C, Aberdam D, Ciatti S, Dunnill MG, McMillan JR, Eady RA, Ortonne JP, Meneguzzi G, et al. (1995) A homozygous nonsense mutation in the alpha 3 chain gene of laminin 5 (LAMA3) in lethal (Herlitz) junctional epidermolysis bullosa. Hum Mol Genet. 4: 959-962.

Kivirikko S, McGrath JA, Pulkkinen L, Uitto J, Christiano AM (1996) Mutational hotspots in the LAMB3 gene in the lethal (Herlitz) type of junctional epidermolysis bullosa. Hum Mol Genet 5:231-237. 
Kivisaari AK, Kallajoki M, Mirtti T, McGrath JA, Bauer JW, Weber F, et al. (2008) Transformation-specific matrix metalloproteinases (MMP)-7 and MMP-13 are expressed by tumour cells in epidermolysis bullosa-associated squamous cell carcinomas. Br J Dermatol 158:778-785.

Kivisaari AK, Kallajoki M, Ala-aho R, McGrath JA, Bauer JW, Konigova R, et al. (2010) Matrix metalloproteinase-7 activates heparin-binding epidermal growth factor-like growth factor in cutaneous squamous cell carcinoma. Br J Dermatol 163:726-735.

Kowal-Vern A, Criswell BK (2005) Burn scar neoplasms: a literature review and statistical analysis. Burns 31:403-413.

Kraemer KH, Lee MM, Scotto J (1987) Xeroderma pigmentosum. Cutaneous, ocular, and neurologic abnormalities in 830 published cases. Arch Dermatol 123:241-250.

Kraemer KH (1993) Xeroderma pigmentosum. In: GeneReviews [Online] Available from: http://www.ncbi.nlm.nih.gov/entrez/query.fcgi?cmd=Retrieve\&db=PubMed\&do pt=Citation\&list_uids=20301571 (Pagon RA BT, Dolan CR , Stephens K ed): University of Washington, Seattle (Accessed June 2011).

Kraemer KH, Lee MM, Andrews AD, Lambert WC (1994) The role of sunlight and DNA repair in melanoma and nonmelanoma skin cancer. The xeroderma pigmentosum paradigm. Arch Dermatol 130:1018-1021.

Kraemer KH, Patronas NJ, Schiffmann R, Brooks BP, Tamura D, DiGiovanna JJ (2007) Xeroderma pigmentosum, trichothiodystrophy and Cockayne syndrome: a complex genotype-phenotype relationship. Neuroscience 145:1388-1396.

Kromberg JG, Castle D, Zwane EM, Jenkins T (1989) Albinism and skin cancer in Southern Africa. Clin Genet 36:43-52.

Kromberg JG, Zwane E, Castle D, Jenkins T (1987) Albinism in South African blacks. Lancet 2:388-389.

Lai-Cheong JE, Tanaka A, Hawche G, Emanuel P, Maari C, Taskesen M, et al. (2009) Kindler syndrome: a focal adhesion genodermatosis. Br J Dermatol 160:233-242.

Lane DP (1992) Cancer. p53, guardian of the genome. Nature 358:15-16.

Lee YA, Stevens HP, Delaporte E, Wahn U, Reis A (2000) A gene for an autosomal dominant scleroatrophic syndrome predisposing to skin cancer (Huriez syndrome) maps to chromosome 4q23. Am J Hum Genet 66:326-330.

Leigh IM, Eady RA, Heagerty AH, Purkis PE, Whitehead PA, Burgeson RE (1988) Type VII collagen is a normal component of epidermal basement membrane, which shows altered expression in recessive dystrophic epidermolysis bullosa. J Invest Dermatol 90:639-642.

Leinonen PT, Hagg PM, Peltonen S, Jouhilahti EM, Melkko J, Korkiamaki T, et al. (2009) Reevaluation of the normal epidermal calcium gradient, and analysis of calcium levels and ATP receptors in Hailey-Hailey and Darier epidermis. J Invest Dermatol 129:1379-1387.

Lewis KG, Weinstock MA (2007) Trends in nonmelanoma skin cancer mortality rates in the United States, 1969 through 2000. J Invest Dermatol 127:2323-2327.

Li J, Yen C, Liaw D, Podsypanina K, Bose S, Wang SI, et al. (1997) PTEN, a putative protein tyrosine phosphatase gene mutated in human brain, breast, and prostate cancer. Science 275:1943-1947. 
Liaw D, Marsh DJ, Li J, Dahia PL, Wang SI, Zheng Z, et al. (1997) Germline mutations of the PTEN gene in Cowden disease, an inherited breast and thyroid cancer syndrome. Nat Genet 16:64-67.

Lohi J, Leivo I, Owaribe K, Burgeson RE, Franssila K, Virtanen I (1998) Neoexpression of the epithelial adhesion complex antigens in thyroid tumours is associated with proliferation and squamous differentiation markers. J Pathol 184:191-196.

Machino H, Miki Y, Teramoto T, Shiraishi S, Sasaki MS (1984) Cytogenetic studies in a patient with porokeratosis of Mibelli, multiple cancers and a forme fruste of Werner's syndrome. Br J Dermatol 111:579-586.

Madariaga J, Fromowitz F, Phillips M, Hoover HC, Jr. (1986) Squamous cell carcinoma in congenital ichthyosis with deafness and keratitis. A case report and review of the literature. Cancer 57:2026-2029.

Malkin D (1994) p53 and the Li-Fraumeni syndrome. Biochim Biophys Acta 1198:197-213.

Mallipeddi R, Wessagowit V, South AP, Robson AM, Orchard GE, Eady RA, et al. (2004) Reduced expression of insulin-like growth factor-binding protein-3 (IGFBP-3) in Squamous cell carcinoma complicating recessive dystrophic epidermolysis bullosa. J Invest Dermatol 122:1302-1309.

Marcuzzi GP, Hufbauer M, Kasper HU, Weissenborn SJ, Smola S, Pfister H (2009) Spontaneous tumour development in human papillomavirus type 8 E6 transgenic mice and rapid induction by UV-light exposure and wounding. J Gen Virol 90:28552864.

Marinkovich MP, Keene DR, Rimberg CS, Burgeson RE (1993) Cellular origin of the dermalepidermal basement membrane. Developmental Dynamics 197:255-267.

Martinez JC, Otley CC, Stasko T, Euvrard S, Brown C, Schanbacher CF, et al. (2003) Defining the clinical course of metastatic skin cancer in organ transplant recipients: a multicenter collaborative study. Arch Dermatol 139:301-306.

Martins V, Vyas J, Chen M, Purdie K, Mein C, South A, et al. (2009) Increased invasive behaviour in cutaneous squamous cell carcinoma with loss of basement-membrane type VII collagen. J Cell Sci 122:1788-1799.

Masini C, Fuchs PG, Gabrielli F, Stark S, Sera F, Ploner M, et al. (2003) Evidence for the association of human papillomavirus infection and cutaneous squamous cell carcinoma in immunocompetent individuals. Arch Dermatol 139:890-894.

Mazereeuw-Hautier J, Bitoun E, Chevrant-Breton J, Man SY, Bodemer C, Prins C, et al. (2007) Keratitis-ichthyosis-deafness syndrome: disease expression and spectrum of connexin 26 (GJB2) mutations in 14 patients. Br J Dermatol 156:1015-1019.

McGrath JA, Leigh IM, Eady RA (1992a) Intracellular expression of type VII collagen during wound healing in severe recessive dystrophic epidermolysis bullosa and normal human skin. Br J Dermatol 127:312-317.

McGrath JA, Schofield OM, Mayou BJ, McKee PH, Eady RA (1992b) Epidermolysis bullosa complicated by squamous cell carcinoma: report of 10 cases. J Cutan Pathol 19:116123.

McGrath JA, Ishida-Yamamoto A, O'Grady A, Leigh IM, Eady RA (1993) Structural variations in anchoring fibrils in dystrophic epidermolysis bullosa: correlation with type VII collagen expression. J Invest Dermatol 100:366-372.

McGrath JA, Gatalica B, Christiano AM, Li K, Owaribe K, McMillan JR, Eady RA, Uitto J. (1995) Mutations in the $180-\mathrm{kD}$ bullous pemphigoid antigen (BPAG2), a 
hemidesmosomal transmembrane collagen (COL17A1), in generalized atrophic benign epidermolysis bullosa. Nat Genet. 11: 83-86.

Micali G, Nasca MR, Innocenzi D, Frasin LA, Radi O, Parma P, et al. (2005) Association of palmoplantar keratoderma, cutaneous squamous cell carcinoma, dental anomalies, and hypogenitalism in four siblings with $46, \mathrm{XX}$ karyotype: a new syndrome. J Am Acad Dermatol 53:S234-239.

Miki Y, Swensen J, Shattuck-Eidens D, Futreal PA, Harshman K, Tavtigian S, et al. (1994) A strong candidate for the breast and ovarian cancer susceptibility gene BRCA1. Science 266:66-71.

Miller DL, Weinstock MA (1994) Nonmelanoma skin cancer in the United States: incidence. J Am Acad Dermatol 30:774-778.

Ming M, Han W, Maddox J, Soltani K, Shea CR, Freeman DM, et al. (2009) UVB-induced ERK/AKT-dependent PTEN suppression promotes survival of epidermal keratinocytes. Oncogene 29:492-502.

Ming M, He YY (2009) PTEN: new insights into its regulation and function in skin cancer. J Invest Dermatol 129:2109-2112.

Nagle RB, Knox JD, Wolf C, Bowden GT, Cress AE (1994) Adhesion molecules, extracellular matrix, and proteases in prostate carcinoma. J Cell Biochem Suppl 19:232-237.

Narod SA, Feunteun J, Lynch HT, Watson P, Conway T, Lynch J, et al. (1991) Familial breastovarian cancer locus on chromosome 17q12-q23. Lancet 338:82-83.

Nelen MR, Padberg GW, Peeters EA, Lin AY, van den Helm B, Frants RR, et al. (1996) Localization of the gene for Cowden disease to chromosome 10q22-23. Nat Genet 13:114-116.

Ng Y, Pourreyron, Salas-Alanis J, Murrell D, McGrath J, Lane E, et al. (2010) Tumour microenvironment is implicated by dermal fibroblast expression profiling in the development of aggressive squamous cell carcinoma in patients with recessive dystrophic epidermolysis bullosa [Abstract]. J Invest Dermatol 130:S83.

Oetting WS, King RA (1993) Molecular basis of type I (tyrosinase-related) oculocutaneous albinism: mutations and polymorphisms of the human tyrosinase gene. Hum Mutat 2:1-6.

Office for National Statistics (2010) Mortality statistics: Deaths registered in 2009 - Review of the national statistician on deaths in england and wales, 2009. Available from: http://www.statistics.gov.uk/downloads/theme_health/dr2009/dr-09.pdf (Accessed May 2011).

Olivier M, Goldgar DE, Sodha N, Ohgaki H, Kleihues P, Hainaut P, et al. (2003) Li-Fraumeni and related syndromes: correlation between tumor type, family structure, and TP53 genotype. Cancer Res 63:6643-6650.

Orihuela E, Tyring SK, Pow-Sang M, Dozier S, Cirelli R, Arany I, et al. (1995) Development of human papillomavirus type 16 associated squamous cell carcinoma of the scrotum in a patient with Darier's disease treated with systemic isotretinoin. J Urol 153:1940-1943.

Orth G, Jablonska S, Favre M, Croissant O, Jarzabek-Chorzelska M, Rzesa G (1978) Characterization of two types of human papillomaviruses in lesions of epidermodysplasia verruciformis. Proc Natl Acad Sci U S A 75:1537-1541.

Ortiz-Urda S, Garcia J, Green CL, Chen L, Lin Q, Veitch DP, et al. (2005) Type VII collagen is required for Ras-driven human epidermal tumorigenesis. Science 307:1773-1776. 
Parma P, Radi O, Vidal V, Chaboissier MC, Dellambra E, Valentini S, et al. (2006) R-spondin1 is essential in sex determination, skin differentiation and malignancy. Nat Genet 38:1304-1309.

Paulus W, Baur I, Liszka U, Drlicek M, Leigh I, Bruckner-Tuderman L (1995) Expression of type VII collagen, the major anchoring fibril component, in normal and neoplastic human nervous system. Virchows Arch 426:199-202.

Pecora AL, Landsman L, Imgrund SP, Lambert WC (1983) Acrokeratosis paraneoplastica (Bazex' syndrome). Report of a case and review of the literature. Arch Dermatol 119:820-826.

Pelisson I, Soler C, Chardonnet Y, Euvrard S, Schmitt D (1996) A possible role for human papillomaviruses and c-myc, c-Ha-ras, and p53 gene alterations in malignant cutaneous lesions from renal transplant recipients. Cancer Detect Prev 20:20-30.

Perry PK, Silverberg NB (2001) Cutaneous malignancy in albinism. Cutis 67:427-430.

Poon PK, O'Brien RL, Parker JW (1974) Defective DNA repair in Fanconi's anaemia. Nature 250:223-225.

Poulikakos PI, Zhang C, Bollag G, Shokat KM, Rosen N (2010) RAF inhibitors transactivate RAF dimers and ERK signalling in cells with wild-type BRAF. Nature 464:427-430.

Pourreyron C, Cox G, Mao X, Volz A, Baksh N (2007) Patients with recessive dystrophic epidermolysis bullosa develop squamous-cell carcinoma regardless of type VII collagen expression. J Invest Dermatol 127:2438-2444.

Purdie KJ, Pourreyron C, Fassihi H, Cepeda-Valdes R, Frew JW, Volz A, et al. (2010) No evidence that human papillomavirus is responsible for the aggressive nature of recessive dystrophic epidermolysis bullosa-associated squamous cell carcinoma. J Invest Dermatol 130:2853-2855.

Radi O, Parma P, Imbeaud S, Nasca MR, Uccellatore F, Maraschio P, et al. (2005) XX sex reversal, palmoplantar keratoderma, and predisposition to squamous cell carcinoma: genetic analysis in one family. Am J Med Genet A 138A:241-246.

Ramoz N, Rueda LA, Bouadjar B, Montoya LS, Orth G, Favre M (2002) Mutations in two adjacent novel genes are associated with epidermodysplasia verruciformis. Nat Genet 32:579-581.

Reed WB, Roenigk H, Dorner W, Welsh O, Martin FJO (1975) Epidermal neoplasms with epidermolysis bullosa dystrophica with the first report of carcinoma with the acquired type. Arch Dermatol Res 253:1-14.

Rodeck U, Uitto J (2007) Recessive dystrophic epidermolysis bullosa-associated squamouscell carcinoma: an enigmatic entity with complex pathogenesis. J Invest Dermatol 127:2295-2296.

Ryynänen M, Knowlton RG, Parente MG, Chung LC, Chu ML, Uitto J (1991) Human type VII collagen: genetic linkage of the gene (COL7A1) on chromosome 3 to dominant dystrophic epidermolysis bullosa. Am J Hum Genet 49:797-803.

Saitoh S, Oiso N, Wada T, Narazaki O, Fukai K (2000) Oculocutaneous albinism type 2 with a $\mathrm{P}$ gene missense mutation in a patient with Angelman syndrome. J Med Genet 37:392-394.

Sakai LY, Keene DR, Morris NP, Burgeson RE (1986) Type VII collagen is a major structural component of anchoring fibrils. J Cell Biol 103:1577-1586.

Sakuntabhai A, Burge S, Monk S, Hovnanian A (1999a) Spectrum of novel ATP2A2 mutations in patients with Darier's disease. Hum Mol Genet 8:1611-1619. 
Sakuntabhai A, Ruiz-Perez V, Carter S, Jacobsen N, Burge S, Monk S, et al. (1999b) Mutations in ATP2A2, encoding a Ca2+ pump, cause Darier disease. Nat Genet 21:271-277.

Sarkar B, Knecht R, Sarkar C, Weidauer H (1998) Bazex syndrome (acrokeratosis paraneoplastica). Eur Arch Otorhinolaryngol 255:205-210.

Sato M, Nishigori C, Lu Y, Zghal M, Yagi T, Takebe H (1994) Far less frequent mutations in ras genes than in the p53 gene in skin tumors of xeroderma pigmentosum patients. Mol Carcinog 11:98-105.

Sato T, Nomura K, Hashimoto I (1995) Expression of collagenase and stromelysin in skin fibroblasts from recessive dystrophic epidermolysis bullosa. Arch Dermatol Res 287:428-433.

Seal S, Thompson D, Renwick A, Elliott A, Kelly P, Barfoot R, et al. (2006) Truncating mutations in the Fanconi anemia J gene BRIP1 are low-penetrance breast cancer susceptibility alleles. Nat Genet 38:1239-1241.

Segrelles C, Ruiz S, Perez P, Murga C, Santos M, Budunova IV, et al. (2002) Functional roles of Akt signaling in mouse skin tumorigenesis. Oncogene 21:53-64.

Sehgal VN, Srivastava G (2005) Darier's (Darier-White) disease/keratosis follicularis. Int J Dermatol 44:184-192.

Sekar SC SC (2008) Huriez syndrome. Indian J Dermatol Venereol Leprol 74:409-410.

Sharma V, Sharma NL, Ranjan N, Tegta GR, Sarin S (2006) Acrokeratosis paraneoplastica (Bazex syndrome): case report and review of literature. Dermatol Online J 12:11.

Siegel DH, Ashton GH, Penagos HG, Lee JV, Feiler HS, Wilhelmsen KC, et al. (2003) Loss of kindlin-1, a human homolog of the Caenorhabditis elegans actin-extracellularmatrix linker protein UNC-112, causes Kindler syndrome. Am J Hum Genet 73:174187.

Skinner BA, Greist MC, Norins AL (1981) The keratitis, ichthyosis, and deafness (KID) syndrome. Arch Dermatol 117:285-289.

Skovbjerg H, Anthonsen D, Lothe IM, Tveit KM, Kure EH, Vogel LK (2009) Collagen mRNA levels changes during colorectal cancer carcinogenesis. BMC Cancer 9:136.

Smith ML, Fornace AJ, Jr. (1997) p53-mediated protective responses to UV irradiation. Proc Natl Acad Sci U S A 94:12255-12257.

Smoller BA, McNutt NS, Carter DM, Gottlieb AB, Hsu A, Krueger J (1990a) Recessive dystrophic epidermolysis bullosa skin displays a chronic growth-activated immunophenotype. Implications for carcinogenesis. Arch Dermatol 126:78-83.

Smoller BR, Krueger J, McNutt NS, Hsu A (1990b) "Activated" keratinocyte phenotype is unifying feature in conditions which predispose to squamous cell carcinoma of the skin. Mod Pathol 3:171-175.

Song IC, Dicksheet S (1985) Management of squamous cell carcinoma in a patient with dominant-type epidermolysis bullosa dystrophica: a surgical challenge. Plast Reconstr Surg 75:732-736.

Srivastava S, Tong YA, Devadas K, Zou ZQ, Sykes VW, Chen Y, et al. (1992) Detection of both mutant and wild-type p53 protein in normal skin fibroblasts and demonstration of a shared 'second hit' on p53 in diverse tumors from a cancerprone family with Li-Fraumeni syndrome. Oncogene 7:987-991.

Starink TM, van der Veen JP, Arwert F, de Waal LP, de Lange GG, Gille JJ, et al. (1986) The Cowden syndrome: a clinical and genetic study in 21 patients. Clin Genet 29:222233. 
Stransky N, Egloff AM, Tward AD, Kostic AD, Cibulskis K, Sivachenko A, et al. (2011) The mutational landscape of head and neck squamous cell carcinoma. Science Epub 2011 July 28. doi: 10.1126/science.1208130.

Summers CG (2009) Albinism: classification, clinical characteristics, and recent findings. Optom Vis Sci 86:659-662.

Suzuki A, de la Pompa JL, Stambolic V, Elia AJ, Sasaki T, del Barco Barrantes I, et al. (1998) High cancer susceptibility and embryonic lethality associated with mutation of the PTEN tumor suppressor gene in mice. Curr Biol 8:1169-1178.

Suzuki A, Itami S, Ohishi M, Hamada K, Inoue T, Komazawa N, et al. (2003) Keratinocytespecific Pten deficiency results in epidermal hyperplasia, accelerated hair follicle morphogenesis and tumor formation. Cancer Res 63:674-681.

Taguchi M, Watanabe S, Yashima K, Murakami Y, Sekiya T, Ikeda S (1994) Aberrations of the tumor suppressor p53 gene and p53 protein in solar keratosis in human skin. $J$ Invest Dermatol 103:500-503.

Tani T, Karttunen T, Kiviluoto T, Kivilaakso E, Burgeson RE, Sipponen P, et al. (1996) Alpha 6 beta 4 integrin and newly deposited laminin- 1 and laminin- 5 form the adhesion mechanism of gastric carcinoma. Continuous expression of laminins but not that of collagen VII is preserved in invasive parts of the carcinomas: implications for acquisition of the invading phenotype. Am J Pathol 149:781-793.

Terrinoni A, Codispoti A, Serra V, Bruno E, Didona B, Paradisi M, et al. (2010) Connexin 26 (GJB2) mutations as a cause of the KID syndrome with hearing loss. Biochem Biophys Res Commun 395:25-30.

Tidman MJ, Eady RA (1985) Evaluation of anchoring fibrils and other components of the dermal-epidermal junction in dystrophic epidermolysis bullosa by a quantitative ultrastructural technique. J Invest Dermatol 84:374-377.

Titeux M, Pendaries V, Tonasso L, Decha A, Bodemer C, Hovnanian A (2008) A frequent functional SNP in the MMP1 promoter is associated with higher disease severity in recessive dystrophic epidermolysis bullosa. Hum Mutat 29:267-276.

Tolar J, Ishida-Yamamoto A, Riddle M, McElmurry RT, Osborn M, Xia L, et al. (2009) Amelioration of epidermolysis bullosa by transfer of wild-type bone marrow cells. Blood 113:1167-1174.

Tyring SK, Chopra V, Johnson L, Fine JD (1989) Natural killer cell activity is reduced in patients with severe forms of inherited epidermolysis bullosa. Arch Dermatol 125:797-800.

Uitto J, Pulkkinen L, Christiano AM (1994) Molecular basis of the dystrophic and junctional forms of epidermolysis bullosa: mutations in the type VII collagen and kalinin (laminin 5) genes. J Invest Dermatol 103:39S-46S.

Uitto J, Pulkkinen L, Christiano AM (1999) The molecular basis of dystrophic forms of epidermolysis bullosa. In: Epidermolysis bullosa: clinical, epidemiologic and laboratory advances and the findings of the national epidermolysis bullosa registry (Fine J-D, Bauer E, McGuire J, Moshell A, eds), Baltimore: The Johns Hopkins University Press., 326350.

Uitto J, Richard G (2004) Progress in epidermolysis bullosa: genetic classification and clinical implications. Am J Med Genet C Semin Med Genet 131C:61-74. 
Varki R, Sadowski S, Uitto J, Pfendner E (2007) Epidermolysis bullosa. II. Type VII collagen mutations and phenotype-genotype correlations in the dystrophic subtypes. J Med Genet 44:181-192.

Vazquez J, Morales C, Gonzalez LO, Lamelas ML, Ribas A (2002) Vulval squamous cell carcinoma arising in localized Darier's disease. Eur J Obstet Gynecol Reprod Biol 102:206-208.

Veness MJ, Porceddu S, Palme CE, Morgan GJ (2007) Cutaneous head and neck squamous cell carcinoma metastatic to parotid and cervical lymph nodes. Head Neck 29:621631.

Vidal, F., Aberdam, D., Miquel, C., Christiano, A. M., Pulkkinen, L., Uitto, J., Ortonne, J.-P., Meneguzzi, G. (1995) Integrin beta-4 mutations associated with junctional epidermolysis bullosa with pyloric atresia. Nat Genet. 10: 229-234.

Vindevoghel L, Chung KY, Davis A, Kouba D, Kivirikko S, Alder H, et al. (1997) A GT-rich sequence binding the transcription factor $\mathrm{Sp} 1$ is crucial for high expression of the human type VII collagen gene (COL7A1) in fibroblasts and keratinocytes. J Biol Chem 272:10196-10204.

Visser R, Arends JW, Leigh IM, Bosman FT (1993) Patterns and composition of basement membranes in colon adenomas and adenocarcinomas. J Pathol 170:285-290.

Viteri A, Munoz A, Barcelo R (2005) Acrokeratosis paraneoplastica (Bazex syndrome) preceeding the diagnosis of metastatic squamous cell carcinoma of the esophagus. $J$ Am Acad Dermatol 52:711-712.

Wagner JE, Ishida-Yamamoto A, McGrath JA, Hordinsky M, Keene DR, Woodley DT, et al. (2010) Bone marrow transplantation for recessive dystrophic epidermolysis bullosa. N Engl J Med 363:629-639.

Waterman EA, Sakai N, Nguyen NT, Horst BAJ, Veitch DP, Dey CN, et al. (2007) A laminincollagen complex drives human epidermal carcinogenesis through phosphoinositol-3-kinase activation. Cancer Res 67:4264-4270.

Watt SA, Pourreyron C, Purdie K, Hogan C, Cole CL, Foster N, et al. (2011) Integrative mRNA profiling comparing cultured primary cells with clinical samples reveals PLK1 and C20orf20 as therapeutic targets in cutaneous squamous cell carcinoma. Oncogene Epub 2001 May 23. doi: 10.1038/onc.2011.180

Wetzels RH, Robben HC, Leigh IM, Schaafsma HE, Vooijs GP, Ramaekers FC (1991) Distribution patterns of type VII collagen in normal and malignant human tissues. Am J Pathol 139:451-459.

Wetzels RH, Schaafsma HE, Leigh IM, Lane EB, Troyanovsky SM, Wagenaar SS, et al. (1992a) Laminin and type VII collagen distribution in different types of human lung carcinoma: correlation with expression of keratins 14, 16, 17 and 18. Histopathology 20:295-303.

Wetzels RH, van der Velden LA, Schaafsma HE, Manni JJ, Leigh IM, Vooijs GP, et al. (1992b) Immunohistochemical localization of basement membrane type VII collagen and laminin in neoplasms of the head and neck. Histopathology 21:459-464.

Woodley DT, Krueger GG, Jorgensen CM, Fairley JA, Atha T, Huang Y, et al. (2003) Normal and gene-corrected dystrophic epidermolysis bullosa fibroblasts alone can produce type VII collagen at the basement membrane zone. J Invest Dermatol 121:1021-1028. 
Woodley DT, Remington J, Huang Y, Hou Y, Li W, Keene DR, et al. (2007) Intravenously injected human fibroblasts home to skin wounds, deliver type VII collagen, and promote wound healing. Mol Ther 15:628-635.

Woodley DT, Hou Y, Martin S, Li W, Chen M (2008) Characterization of molecular mechanisms underlying mutations in dystrophic epidermolysis bullosa using sitedirected mutagenesis. J Biol Chem 283:17838-17845.

Wooster R, Bignell G, Lancaster J, Swift S, Seal S, Mangion J, et al. (1995) Identification of the breast cancer susceptibility gene BRCA2. Nature 378:789-792.

Xie J, Murone M, Luoh SM, Ryan A, Gu Q, Zhang C, et al. (1998) Activating Smoothened mutations in sporadic basal-cell carcinoma. Nature 391:90-92.

Yamamoto K, Imakiire A, Miyagawa N, Kasahara T (2003) A report of two cases of Werner's syndrome and review of the literature. J Orthop Surg (Hong Kong) 11:224-233.

Yasaka N, Kawabe K, Furue M, Tamaki K, Ishibashi Y (1994) Altered expression of NU-T2BMZ antigen and type VII collagen in basal cell epithelioma. J Dermatol Sci 7:136141.

Yazdanfar A, Hashemi B (2009) Kindler syndrome: report of three cases in a family and a brief review. Int J Dermatol 48:145-149.

Yuen WY, Jonkman MF (2011) Risk of squamous cell carcinoma in junctional epidermolysis bullosa, non-Herlitz type: Report of 7 cases and a review of the literature. J Am Acad Dermatol Epub 201131 May. doi: 10.1016/j.jaad.2010.07.006. 


\section{SKIN CANCERS}

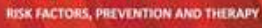

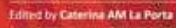

\section{Skin Cancers - Risk Factors, Prevention and Therapy \\ Edited by Prof. Caterina La Porta}

ISBN 978-953-307-722-2

Hard cover, 272 pages

Publisher InTech

Published online 14, November, 2011

Published in print edition November, 2011

Skin cancers are the fastest growing type of cancer in the United States and represent the most commonly diagnosed malignancy, surpassing lung, breast, colorectal and prostate cancer. In Europe, the British Isles have been the highest rates of skin cancer in children and adolescents. The overall idea of this book is to provide the reader with up to date information on the possible tools to use for prevention, diagnosis and treatment of skin cancer. Three main issues are discussed: risk factors, new diagnostic tools for prevention and strategies for prevention and treatment of skin cancer using natural compounds or nano-particle drug delivery and photodynamic therapy.

\section{How to reference}

In order to correctly reference this scholarly work, feel free to copy and paste the following:

Yi-Zhen Ng, Jasbani H.S Dayal and Andrew P. South (2011). Genetic Predisposition to Cutaneous Squamous Cell Carcinoma, Skin Cancers - Risk Factors, Prevention and Therapy, Prof. Caterina La Porta (Ed.), ISBN: 978-953-307-722-2, InTech, Available from: http://www.intechopen.com/books/skin-cancers-risk-factorsprevention-and-therapy/genetic-predisposition-to-cutaneous-squamous-cell-carcinoma

\section{INTECH}

open science | open minds

\section{InTech Europe}

University Campus STeP Ri Slavka Krautzeka 83/A 51000 Rijeka, Croatia Phone: +385 (51) 770447

Fax: +385 (51) 686166 www.intechopen.com

\section{InTech China}

Unit 405, Office Block, Hotel Equatorial Shanghai No.65, Yan An Road (West), Shanghai, 200040, China 中国上海市延安西路65号上海国际贵都大饭店办公楼 405 单元 Phone: +86-21-62489820

Fax: $+86-21-62489821$ 
(C) 2011 The Author(s). Licensee IntechOpen. This is an open access article distributed under the terms of the Creative Commons Attribution 3.0 License, which permits unrestricted use, distribution, and reproduction in any medium, provided the original work is properly cited. 